\title{
The mineralogic and isotopic fingerprint of equatorial carbonates: Kepulauan Seribu, Indonesia
}

\author{
Dwi Amanda Utami ${ }^{1,2,3} \cdot$ Lars Reuning $^{2} \cdot$ Maximillian Hallenberger ${ }^{1} \cdot$ Sri Yudawati Cahyarini $^{3}$
}

Received: 9 July 2020 / Accepted: 29 November 2020 / Published online: 18 January 2021

(c) The Author(s) 2021

\begin{abstract}
Kepulauan Seribu is an isolated patch reef complex situated in the Java Sea (Indonesia) and is a typical example for a humid, equatorial carbonate system. We investigate the mineralogical and isotopic fingerprint of Panggang, one of the reef platforms of Kepulauan Seribu, to evaluate differences to other carbonate systems, using isotope in combination with XRD and SEM analysis. A characteristic property of shallow water $(<20 \mathrm{~m})$ sediments from Kepulauan Seribu is their increased LMC content $(\sim 10 \%)$ derived from some genera of rotaliid foraminifers and bivalves. The relative abundance of these faunal elements in shallow waters might be related to at least temporary turbid conditions caused by sediment-laden river runoff. This influence is also evidenced by the presence of low amounts of siliciclastic minerals below the regional wave base. Kepulauan Seribu carbonates are characterized by very low $\delta^{13} \mathrm{C}$ and $\delta^{18} \mathrm{O}$ values. This is related to the isotopically depleted riverine input. The $\delta^{13} \mathrm{C}_{\mathrm{DIC}}$ in riverine water is reduced by the contribution of ${ }^{12} \mathrm{C}$ from riverside mangroves. Deep atmospheric convection and intensive rains contribute ${ }^{18} \mathrm{O}$-depleted freshwater in the river catchments, finally reducing salinity in the Java Sea. The depleted $\delta^{13} \mathrm{C}$ signature in carbonates is further enhanced by the lack of green algae and inorganic carbonates and abundance of coral debris. Low $\delta^{18} \mathrm{O}$ values in carbonates are favored by the high water temperatures in the equatorial setting. Since equatorial carbonates in SE Asia, including the Java Sea, are typically influenced by high turbidity and/or river runoff, the observed distinctively low isotope values likely are characteristic for equatorial carbonate systems in the region.
\end{abstract}

Keywords Patch reefs $\cdot$ Oxygen isotopes $\cdot$ Carbon isotopes $\cdot$ SE Asia $\cdot$ Humid equatorial climate $\cdot$ Maritime continent

\section{Introduction}

During the last decade the awareness has grown that carbonate systems in the humid equatorial zone have common characteristics that distinguishes them from carbonates in more arid regions (Tomascik et al. 1997; Wilson 2008). Features of these equatorial carbonates include the common

Supplementary Information The online version contains supplementary material available at https://doi.org/10.1007/s0053 1-020-01968-9.

Dwi Amanda Utami

dwi.amanda.utami@rwth-aachen.de;

dwi.amanda.utami@lipi.go.id

1 Geological Institute, Energy and Mineral Resources Group, RWTH Aachen University, Aachen, Germany

2 Institute of Geosciences, Kiel University, Kiel, Germany

3 Geotechnology Research Center, Indonesian Institute of Sciences, Bandung, Indonesia occurrence of photozoan assemblages adapted to oligophotic (low light) conditions, common elements of the Heterozoan Association and mixed carbonate/clastic deposits. Humid equatorial carbonates are also characterized by a lack of coated grains, aggregates, chemically precipitated mud and the absence of associated evaporites (Wilson 2002). They typically occur in a zone between $15 / 20^{\circ} \mathrm{N}$ and $15 / 20^{\circ} \mathrm{S}$ in areas with warm $\left(>22^{\circ} \mathrm{C}\right)$ surface waters and heavy precipitation (> $1500 \mathrm{~mm}$ per annum; Wilson, 2012). Due to the increased precipitation, carbonate deposition takes place in shelfal waters of normal to reduced salinity and high clastic influx. River runoff and upwelling cause increased nutrient concentrations in surface waters, which in turn lead to a shallow position of the photic zone.

A key region for the study of these humid equatorial carbonates is SE Asia, where the shallow shelfs are strongly affected by river runoff and/or upwelling (Tomascik et al. 1997; Wilson 2002). The diversity of environments and habitats renders SE Asia an ideal natural laboratory to investigate the variability of equatorial carbonate processes 
and deposits (Tomascik et al. 1997; Wilson 2002, 2008). Sediment discharge from each of the four largest SE Asian islands varies from $\mathrm{ca} 300$ to 1650 million tons/year (Milliman et al. 1999), leading to high turbidity and nutrient concentration in surface waters. Depth of abundant coral growth in SE Asian reefs is therefore limited to approximately $20-30 \mathrm{~m}$ and is considered among the shallowest in the world (Schlager 1992; Wilson 2008). This shallow photic zone corresponds with low light penetration in an oligo-mesotropic region characterized by nutrient input from river runoff, upwelling and plankton blooms (Wilson 2008). Due to these environmental conditions, SE Asian carbonates can be considered as typical equatorial carbonate systems.

The low salinity in the semi-enclosed seas of SE Asia also leads to a relatively low aragonite supersaturation compared to more arid regions, such as the tropical, western Atlantic (TWA). The development of Cenozoic carbonate systems in SE Asia is thought to be strongly influenced by regional changes in nutrient input and precipitation (Wilson 2008). Late Oligocene carbonates from SE Asia were often characterised by calcitic dominated assemblages. This was likely promoted by the decreased aragonite supersaturation of the low salinity waters in the semi-enclosed seas of SE Asia (Wilson 2012). An increase of river runoff and associated decrease in aragonite supersaturation is also held responsible for a shelf wide switch from inorganic aragonite to bioclastic calcite dominated sedimentation on the tropical NW Shelf of Australia during the early Holocene (Hallenberger et al. 2019; Ishiwa et al. 2019); a process which seems to have occurred repeatedly during the Pleistocene (Gallagher et al. 2018). Studies of modern carbonate systems from northern Australia and SE Asia suggest that faunal assemblages from the oligophotic zone are relatively calcite-rich (Wilson and Vecsei 2005; Wilson 2012). Generally, this change from coral dominated euphotic to foramol dominated oligophotic zones takes place in a water depth of around $20 \mathrm{~m}$, but locally can be as shallow as $6 \mathrm{~m}$ in turbid coastal water (Wilson and Vecsei 2005).

Equatorial carbonates share some similarities with cool water systems including the abundance of calcitic components and heterozoan elements. In some cases, this can complicate the distinction between non-tropical and equatorial carbonates (Wilson and Vecsei 2005). Wilson (2012), therefore, recommended the use of additional geochemical and isotopic proxies to identify warm temperatures and low salinities associated with regional equatorial carbonates in the rock record. However, stable isotope studies from modern SE Asia that could be used as a template for comparison with fossil counterparts are still missing. It is also unclear if the predominance of calcitic bioclasts, that is apparent in the oligophotic zone of many carbonate systems in SE Asia, is visible in the mineralogy of the coral dominated shallow water area. In this study, we investigate how far the mineralogy and stable isotope signature of shallow water $(<20 \mathrm{~m})$ equatorial carbonate from Kepulauan Seribu in the Java Sea is distinct from other carbonate systems. Stable isotope $\left(\delta^{13} \mathrm{C}\right.$ and $\left.\delta^{18} \mathrm{O}\right)$ analysis in combination with $\mathrm{X}$-ray diffraction (XRD) and Scanning Electron Microscopy (SEM) is used to provide a fingerprint for equatorial carbonates from SE Asia. This data might be used as a template for comparison with carbonates in the rock record.

\section{Study area}

Situated in the Java Sea, Kepulauan Seribu (The Thousand Islands) consists of numerous coral reef islands ranging in size from a few meters across to length greater than one kilometer. From about $10 \mathrm{~km}$ off the northwest Java coastline, the island chain extends for about $50 \mathrm{~km}$ into the Java Sea. Kepulauan Seribu is situated on the NNE-SSW structural high of the Seribu platform, which is separated from the Sunda Basin towards the west and Arjuna basin to the east by the active N-S oriented Seribu Fault system (Scrutton 1976a). The north-south elongation of the platform is largely controlled by the regional fault pattern that was established during the early Cenozoic and reactivated at various times since (Park et al. 2010). The patch reef system of Kepulauan Seribu is located on the shallow Sunda Shelf where it rises from a water depth of $30-50 \mathrm{~m}$ to the sea surface. A deep and several kilometers wide, east-west oriented channel separates Pari Island to the south from most other islands to its north (Fig. 1). It appears that this channel forms an important hydrologic barrier, channeling the sediment-laden coastal waters off Java and Kalimantan away from the reef (Tomascik et al. 1997; Jordan 1998). The reefal buildups on the platform vary in size and shape but most of them are elongated in a roughly east-west orientation. This pronounced orientation is inherited from the Pleistocene drainage pattern which was abandoned and truncated by river capture prior to the Holocene transgression (Park et al. 2010). The islands of Kepulauan Seribu are considered to be located in a relatively sheltered position protected from severe storms and ocean swells due to the fact that it is surrounded by major landmasses, such as Sumatra, Java and Kalimantan (Fig. 1).

The controlling influence on modern reef growth and morphology in Kepulauan Seribu is believed to be the seasonal change in wind and current directions (Scrutton 1976a). The Java Sea is characterized by a monsoonal climate with a seasonal reversal between the West Monsoon (December-February), and the East Monsoon (April-October). The West Monsoon winds are known to be stronger than the East Monsoon winds, but less persistent (3 vs. 7 months). The East Monsoon winds therefore are the dominant factor for the net sediment transport (Poerbandono 

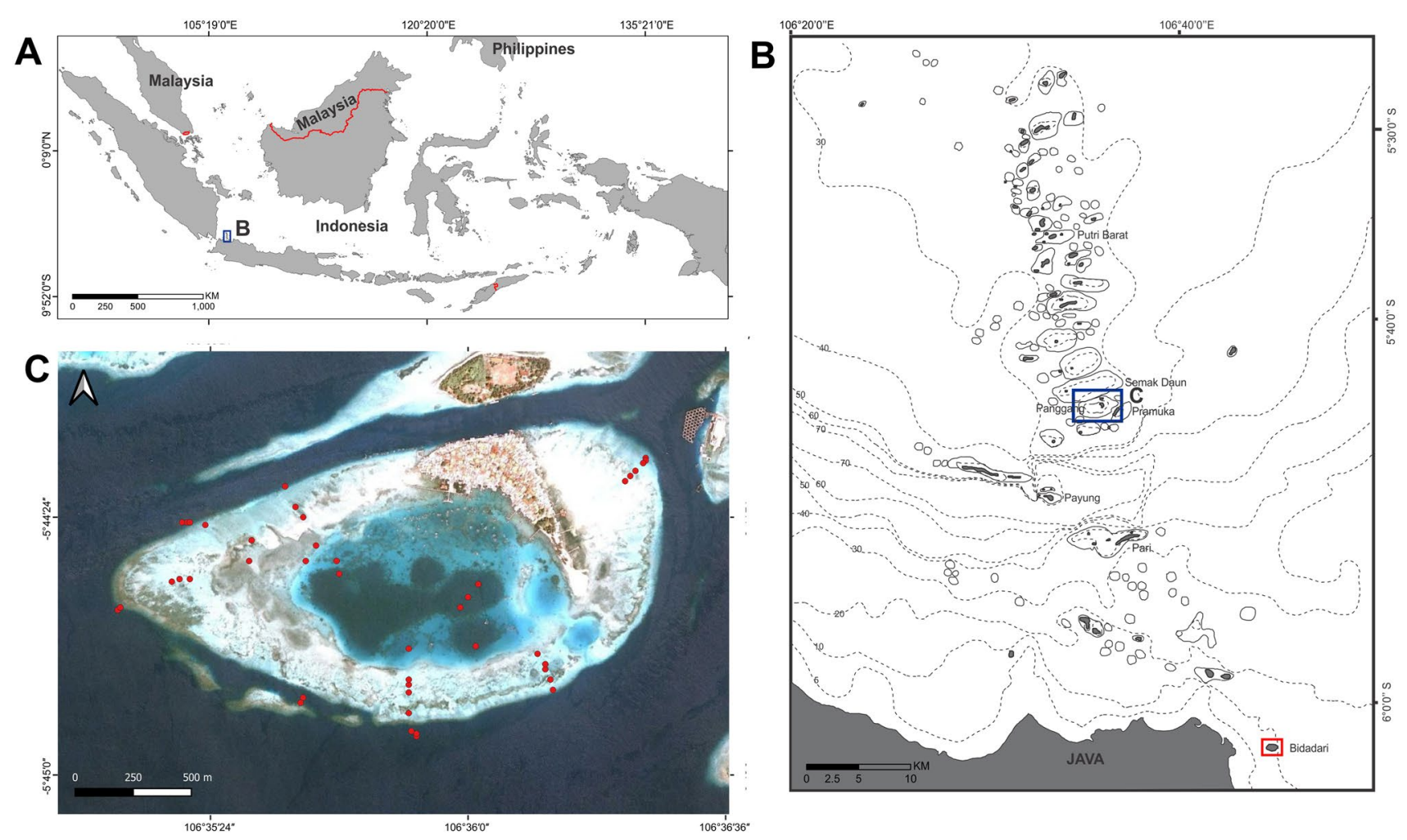

Fig. 1 a Map of Indonesia, surrounding countries, and the study area (blue box). b Bathymetry in the vicinity of Kepulauan Seribu (basemap from National Bathymetry, Indonesia Geospatial Information Agency. Available on http://tides.big.go.id/DEMNAS/). Location

2016). The climate in Kepulauan Seribu is tropical with relative humidity of 80-90\% (Tomascik et al. 1997). The maximum sea surface temperature (SST) is observed in April $\left(29.8^{\circ} \mathrm{C}\right)$ and minimum in January $\left(28.6{ }^{\circ} \mathrm{C}\right)$ (Cahyarini et al. 2016). Surface salinity in the Java Sea (30-34\%o) is well below normal open ocean levels, reaching as low as $22 \%$ in the vicinity of some of the larger river mouths. The low salinity of the Java Sea is due to heavy precipitation and intensive river runoff from Java and Kalimantan (Sofian and Kozai 2007). The water column of the shallow western Java Sea is well mixed and shows little temperature or salinity stratification (Hamzah et al. 2020).

Water along Kepulauan Seribu is highly eutrophic (Baum et al. 2015). Seasonal variability of Chlorophyll- $\alpha$ distribution in the Java Sea is influenced by monsoon, through water exchange with adjacent seas and nutrient supply from river discharge (Koropitan and Ikeda 2016). In the eastern Java Sea, episodic upwelling leads to phytoplankton blooms during the East Monsoon (Koropitan and Ikeda 2016). The role of riverine nutrient input during the West Monsoon (rainy season) is limited to coastal regions (Koropitan and Ikeda 2016). The reefs in Kepulauan Seribu are directly influenced by intense anthropogenic pressure from local as well as regional sources (Baum et al. 2015). Polluted water masses of Panggang is indicated by the blue box, and Bidadari is indicated by the red box. c Satellite image showing Panggang reef platform. Sampling spots are indicated as red dots (satellite image from Google Earth)

from the Greater Jakarta Area are considered to affect reefs in nearshore areas close to river mouths around Jakarta Bay, while localized effects of anthropogenic stressors are more important for reef in the central and northern reefs of Kepulauan Seribu (Damar et al. 2012; Farhan and Lim 2012; Baum et al. 2015).

Each island and platform of Kepulauan Seribu is built up from the skeletal debris of coral reefs which rim the platform margins (Jordan 1998). The steep reef front extends seaward from the reef crest to a depth of about $15 \mathrm{~m}$. Well-developed reef facies occur down to a depth of about 16-18 m (Jordan 1998), whereas reef development is restricted to an even shallower depth of 3-10 m around $40 \mathrm{~km}$ towards the south in Jakarta Bay (Baum et al. 2015). Reef framework builders at Kepulauan Seribu consist of a diverse fauna of IndoPacific corals and encrusting red algae. Below the base of continuous reef development, occurs a transition zone of small reef knolls or coralgal knobs that are surrounded by unconsolidated sediments. In water depths of about $24 \mathrm{~m}$, the seafloor becomes entirely sediment and begins to slope less steeply. Below the reef and near reef zone, in a depth from 27 to $88 \mathrm{~m}$ occurs a foraminiferal molluscan packstone facies that is rich in terrigenous mud. The dominant bioclasts are benthic foraminifers, mollusc and coral fragments 
(Jordan 1998). The sedimentation on the shelf further away from the direct influence of the reef system is dominated by siliciclastic mud.

Statistical analyses based on texture and composition reveal four sedimentary facies in the shallow waters $(<20 \mathrm{~m})$ of the Kepulauan Seribu: coral grainstone, coral packstone/ grainstone, coral-mollusc packstone and mollusc wackestone (Utami et al. 2018). The occurrence of mollusc wackestone in the lagoon is controlled by water depth, while the sand apron and reef front do not show significant facies separation with water depth. Environmental facies maps were derived from remote sensing data (Utami et al. 2018): The sand apron can be subdivided into three facies with either no, sparse, or dense seagrass cover. One facies is further characterized by active coral growth. The deeper water zone can be separated into a shallow and a deep subtidal part of lagoons and platform margins. Distribution is therefore mainly controlled by water depth, density of seagrass cover and coral abundance (Utami et al. 2018). The satellite-derived environmental facies correlated only in the lagoon directly with sedimentary facies. No direct correlation of environmental facies to sedimentary facies exists in the sand apron due to the heterogeneity and complexity of the environment (Utami et al. 2018).

Carbonate sediments from the shallow water $(<20 \mathrm{~m})$ zone of the Panggang reef platform, Kepulauan Seribu serve as the basis of this study (Fig. 1). Panggang is an atoll-like reef with an approximate area of $3.2 \mathrm{~km}^{2}$ with a central lagoon surrounded by reef and sand apron facies. From the reef flat, the water depth increases from about $1 \mathrm{~m}$ to about $20 \mathrm{~m}$ in the deepest part of the lagoon. The sand apron on the eastern and western side of the lagoon is roughly two times wider compared to the sand apron on the northern and southern side. Only one small inlet traverses the sand aprons allowing very limited connection between the lagoon and the open sea. Panggang Island has the highest population density in Kepulauan Seribu, with more than 1000 people per $\mathrm{km}^{2}$.

\section{Methods}

A total of 45 surface sediment samples were collected from Panggang reef platform, Kepulauan Seribu. In shallow water, sediments were collected by hand and water depth was measured using a marked stick. Sampling in the lagoon and at the reef slope was conducted by scuba diving and water depth was determined using the diving gear. In the laboratory, samples were washed in fresh water and dried using an oven set to $70{ }^{\circ} \mathrm{C}$ for $7 \mathrm{~h}$. Dried samples were first sieved through a $125 \mu \mathrm{m}$ sieve and split of the coarse fraction was stored in a glass bottle for later point counting analysis. The remaining portion of the $>125 \mu \mathrm{m}$ fraction was sieved through $250 \mu \mathrm{m}, 500 \mu \mathrm{m}$, $1 \mathrm{~mm}$, and $2 \mathrm{~mm}$ sieves. All individual grainsize fractions were weighed. Mean grainsize and sorting were calculated using the software Gradistat (Blott and Pye 2001). Point counting analysis was done on the split of the $>125 \mu \mathrm{m}$ fraction by counting 300 grains under a binocular microscope. The results of these analyses were reported previously in Utami et al. (2018). Here, we present data on the mineralogy, texture and isotopic composition of the same sample set.

Mineralogy was analyzed using a Bruker D8 X-ray diffractometer equipped with a $\mathrm{Cu}$-anode, a secondary graphite monochromator and a scintillation counter. Forty-five bulk surface sediment samples covering all sedimentary facies (Utami et al. 2018) were oven-dried, ground and mounted on sample holders. Additionally, the mineralogy of the $<125 \mu \mathrm{m}$ fraction from five of these samples and five individual bivalve shells was measured separately. All selected bivalve shells were clean and devoid of incrustations or epibenthos. All measurements were conducted over an angle field of $48^{\circ}\left(16^{\circ}-64^{\circ}\right)$ with a step size of $0.02^{\circ}$ per five seconds. Identification and quantification of different mineral phases was achieved by standard Rietveld refinement using the software Profex (ver. 3.14.0). Standard analytical error is $\pm 2 \%$. A total of 20 weight percent of corundum was added to each sample as an internal standard. This standard was systematically overestimated during Rietveld refinement (avg. 4\%), which was attributed to the occurrence of amorphous silica in the form of sponge needles. The $\mathrm{MgCO}_{3}$ content of calcite (in mol \%) was determined using the shift in the position of the $\mathrm{d}(104)$ peak (Lumsden 1979). The standard error is $\pm 0.15 \%$ on the mean composition.

Measurements of $\delta^{13} \mathrm{C}$ and $\delta^{18} \mathrm{O}$ values on 15 bulk and five fine fraction samples were made with a Finnigan MAT 253 mass spectrometer connected to a Kiel IV carbonate preparation device at the Leibniz Laboratory, Kiel University. Additionally, nine individual benthic foraminifers (Calcarina, Amphistegina and Sorites) and five individual bivalve shells were measured separately. Bivalve shells were ground to powder before measurement. All Calcarina and Amphistegina, as well as one individual Sorites were split into two aliquots and measured as subsamples. Standard external error is better than $\pm 0.05 \%$ for $\delta^{13} \mathrm{C}$ and $\pm 0.08 \%$ or for $\delta^{18} \mathrm{O}$ (standards NBS 19 and 20). $\delta^{13} \mathrm{C}$ and $\delta^{18} \mathrm{O}$ values are reported in \%o versus the Vienna PeeDee belemnite (V-PDB). A core of $68 \mathrm{~cm}$ length was drilled in September 2005 from a massive Porites coral in the Kepulauan Seribu complex, inshore of Bidadari Island at site $6^{\circ} 01^{\prime} 55^{\prime \prime} \mathrm{S}, 106^{\circ} 44^{\prime} 47^{\prime \prime} \mathrm{E}$ (Fig. 1) from $3 \mathrm{~m}$ water depth (Cahyarini et al. 2016). $\delta^{13} \mathrm{C}$ and $\delta^{18} \mathrm{O}$ values were measured at the Stable Isotope Laboratory, Vrije University, Amsterdam. For the analysis, the samples were reacted with $100 \% \mathrm{H}_{3} \mathrm{PO}_{4}$ at $75{ }^{\circ} \mathrm{C}$ in a Kiel 
Device connected to a Finnigan MAT 252 mass spectrometer. Standard external error is $\pm 0.05 \%$ o for $\delta^{13} \mathrm{C}$ and $\pm 0.08 \%$ for $\delta^{18} \mathrm{O}$ (standards NBS 19 and GICS).

A total of 16 selected samples of the $<125 \mu \mathrm{m}$ fraction were further analysed using scanning electron microscopy in the SEM laboratory of FMIPA (Institut Teknologi Bandung) and the SEM/EDS laboratory of UPP Chevron-Prodi Geologi (Institut Teknologi Bandung). Satellite images were acquired from Google Earth (http://www. google.com/earth). The inverse distance weighting tool of QGIS (ver. 3.14.1-Pi) was used to interpolate data between the sampling points for the generation of maps. All statistical analyses were performed using PAST (Hammer et al. 2001). The Levenés test was used to check if homogeneity of variances was met. The non-parametric Mann-Whitney $U$ test was used for pairwise comparisons of median values. The non-parametric Kruskal-Wallis test for independent samples was used to examine the medians of $\delta^{13} \mathrm{C}$ and $\delta^{18} \mathrm{O}$ values in different sedimentary facies. The significance level for all analysis was set at $95 \%$.

\section{Results}

\section{Mineralogy}

Sediments in Kepulauan Seribu are mostly composed of biogenic grains, most notably corals and molluscs, with minor components including benthic foraminifers, echinoderms, red algae and the green alga Halimeda. Non-skeletal grains are very rare and restricted to faecal pellets and aggregates cemented by red algae or serpulids (Table 1) (Scrutton 1976b; Utami et al. 2018). SEM investigation confirms that the fine fraction of sediments in Kepulauan Seribu is largely a product of skeletal breakdown (Fig. 2). X-ray diffraction results confirm that surface sediment on the Panggang reef platform in the central part of Kepulauan Seribu is composed mainly of carbonate minerals with small percentages of siliciclastic minerals. Aragonite is the dominant mineral and its contribution varies between 72 and $88 \%$, with a mean of $82 \%$ (Table 1, Fig. 3). High magnesium calcite (HMC) and low magnesium calcite (LMC) contents are fairly equal throughout the island, for $\mathrm{HMC}$, the value ranges from 5 to

Table 1 Average values of grain types and bulk mineralogy for each sedimentary facies (\%). Grain types are reported as $\%$ of $>125 \mu \mathrm{m}$ fraction, fines $(<125 \mu \mathrm{m})$ as $\%$ of total sediment

\begin{tabular}{|c|c|c|c|c|c|c|c|c|c|c|c|c|c|c|c|}
\hline Facies & Coral & Red Algae & Hal & Mollusc & Foram & Echi & $\mathrm{N}-\mathrm{S}$ & other & Fines & ARA & HMC & LMC & Qz & $\mathrm{Sm}$ & $\begin{array}{l}\mathrm{Mg} \\
(\%)\end{array}$ \\
\hline $\mathrm{C} \mathrm{G}$ & 58.8 & 5.5 & 1.7 & 19.5 & 8.0 & 4.2 & 1.1 & 1.1 & 6.2 & 80 & 9 & 10 & 1 & 0 & 14.2 \\
\hline $\mathrm{C} \mathrm{P} / \mathrm{G}$ & 53.7 & 3.4 & 3.5 & 28.2 & 4.9 & 3.9 & 0.3 & 2.2 & 7.0 & 82 & 8 & 9 & 1 & 0 & 14.2 \\
\hline C-M P & 48.1 & 3.8 & 2.5 & 28.1 & 5.6 & 6.1 & 0.7 & 5.0 & 23.4 & 81 & 9 & 9 & 1 & Trace & 13.8 \\
\hline M W & 24.0 & 1.3 & 0.8 & 40.7 & 3.6 & 5.7 & 2.4 & 21.5 & 51.5 & 77 & 8 & 11 & 2 & 2 & 13.0 \\
\hline
\end{tabular}

C G Coral Grainstone, $C P / G$ Coral Packstone/Grainstone, $C-M$ P Coral-Mollusc Packstone, $M W$ Mollusc Wackestone, Hal Halimeda, Foram foraminifers, Echi echinoderm, $N-S$ non-skeletal, $A R A$ aragonite, $H M C$ high magnesium calcite, $L M C$ low magnesium calcite, $Q z$ quartz, Sm smectite, $\mathrm{Mg}(\%)$ mole $\% \mathrm{MgCO}_{3}$ in $\mathrm{Mg}$-Calcite

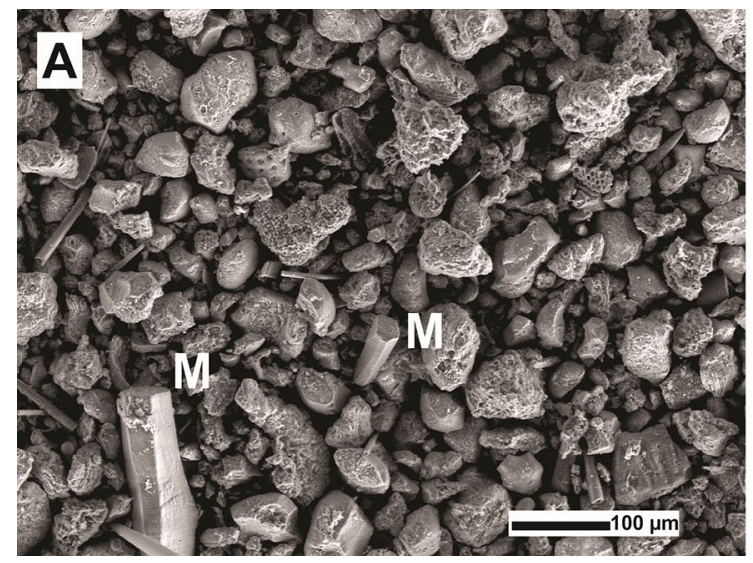

Fig. 2 SEM images of the fine fraction: a Sample MPG 11P from the southern reef flat. Sediment constituents are mostly bioclasts formed by skeletal breakdown including calcitic (LMC) prisms from bivalve

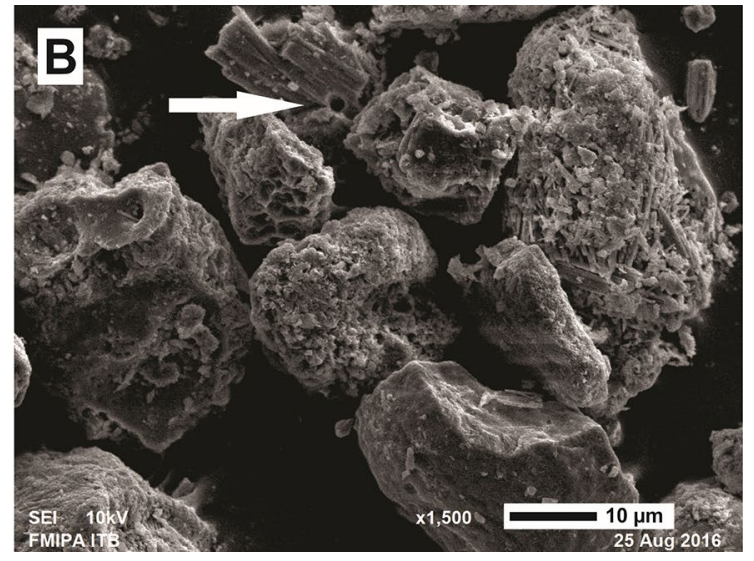

shells (M). b Sample MPG 41L from the northwestern reef flat. Arrow points at open microboring 


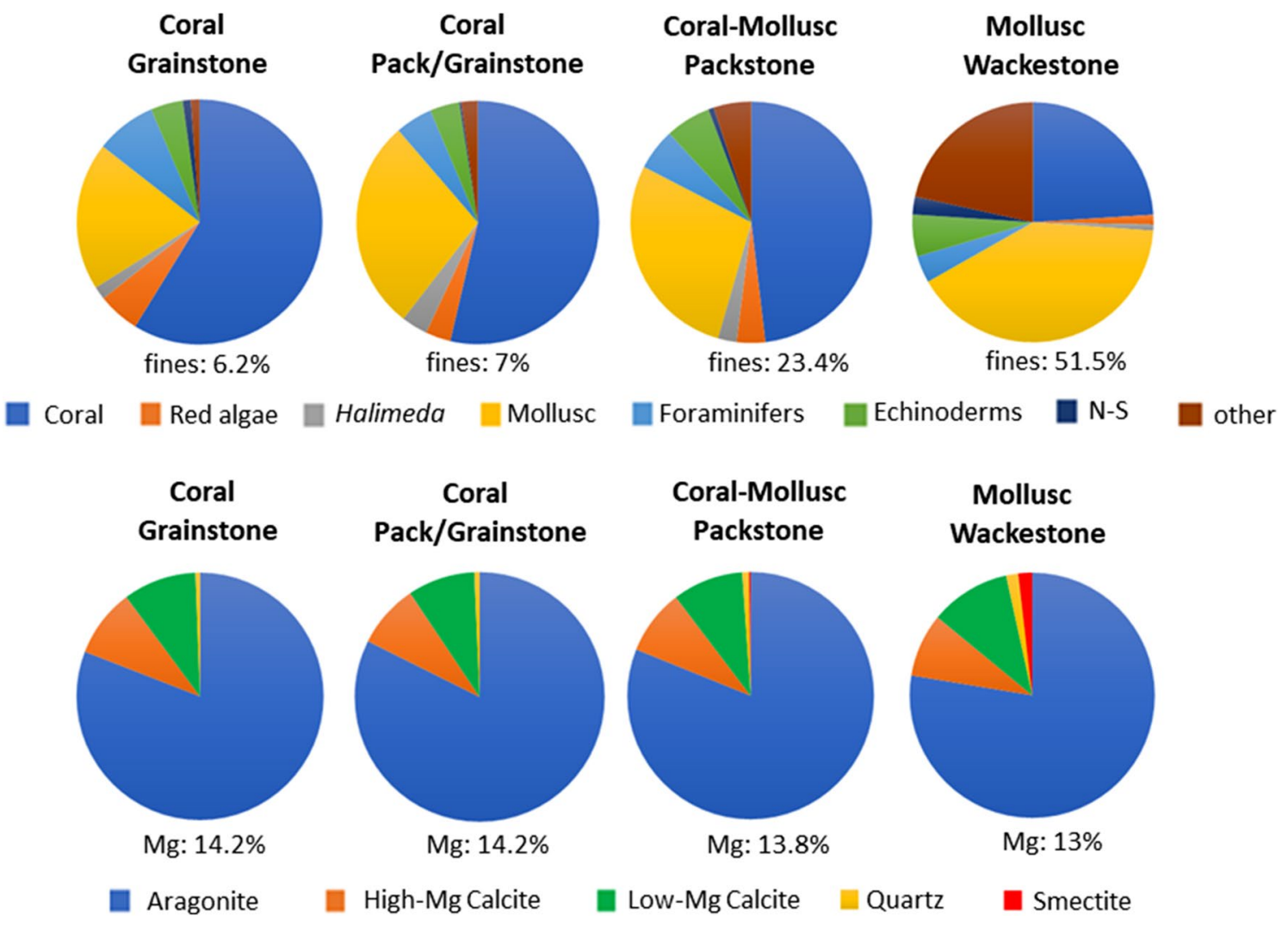

Fig. 3 Composition and mineralogy of each sedimentary facies in $\%$ of $>125 \mu \mathrm{m}$ fraction as indicated in Table $1 . \mathrm{Mg}: \mathrm{mole} \% \mathrm{MgCO}$ in $\mathrm{Mg}$ Calcite

$16 \%$ with a mean of $8 \%$, for LMC the value varies between 5 and $17 \%$ with a mean of $9 \%$ (Fig. 4). Quartz composes only a minor fraction of the total bulk sample, with a maximum of $3 \%$ and a mean of $1 \%$. From 45 bulk samples tested, three samples show smectite contents between 2 and $9 \%$.

Throughout all sedimentary facies (Utami et al. 2018), the mineralogical composition varies only slightly (Table 1, Fig. 3). The HMC content is very similar in all facies, with an average value of $8.5 \%$. The $\mathrm{MgCO}_{3}$ content in $\mathrm{HMC}$ varies between 13 and $14.2 \%$ in mollusc wackestone and coral grainstone facies, respectively. The content of LMC is equal or higher compared to HMC in all facies. The highest aragonite $(82 \%)$ and lowest LMC contents $(9 \%)$ are found in the coral packstone/grainstone facies. The mollusc wackestone facies shows the lowest aragonite (77\%) and highest LMC (11\%) content. The highest siliciclastic content is present in the mollusc wackestone facies (quartz: $2 \%$, smectite: $2 \%$ ).

In addition, the mineralogy of the fine fraction $(<125 \mu \mathrm{m})$ was measured for five samples (Table 2 and Fig. 5). Compared to their respective bulk samples, the fine fraction shows $\sim 1 \%$ higher quartz and significantly higher (9\%) smectite contents. If only the carbonate composition is considered, on average, the fine fraction shows lower aragonite (bulk: 79\%, <125 $\mu \mathrm{m}$ : 73\%), higher HMC (bulk: 10\%, < $125 \mu \mathrm{m}: 14 \%$ ) and nearly equal LMC (bulk: $10 \%,<125 \mu \mathrm{m}: 11 \%$ ) contents. XRD analysis confirmed that all of the five individual bivalve shells are bimineralic, containing predominantly aragonite (90\%) and LMC (10\%) as a subordinate phase.

\section{Stable isotopes of carbonates}

Carbon isotope values $\left(\delta^{13} \mathrm{C}\right)$ range from -1.3 to $0.9 \%$ and oxygen isotopes $\left(\delta^{18} \mathrm{O}\right)$ from -3.4 to $-4.9 \%$ for bulk sediment (Fig. 6). The fine fraction $(<125 \mu \mathrm{m})$ samples did not show a systematic offset in their isotope values with respect to their bulk samples (Fig. 6). Coral abundance is negatively correlated with bulk sediment $\delta^{13} \mathrm{C}$ $(r=-0.52 ; p=0.04)$ and $\delta^{18} \mathrm{O}(r=-0.79 ; p<0.01$; Table 3), while mollusc abundance shows a positive correlation with $\delta^{13} \mathrm{C}(r=0.58 ; p=0.02)$ and $\delta^{18} \mathrm{O}(r=0.79$; $p<0.01)$. A negative correlation is also apparent for the relationship between the abundance of aragonite and $\delta^{18} \mathrm{O}(r=-0.7 ; p \leq 0.01)$. Aragonite and $\delta^{13} \mathrm{C}$ also show a weak negative correlation $(r=-0.43, p=0.11)$. Coral isotope values from Bidadari (Fig. 6) are centered around $-3 \%$ o $\delta^{13} \mathrm{C}$ and $-6 \% \delta^{18} \mathrm{O}$ and lower compared to the bulk samples. Isotope values from bivalves and benthic 

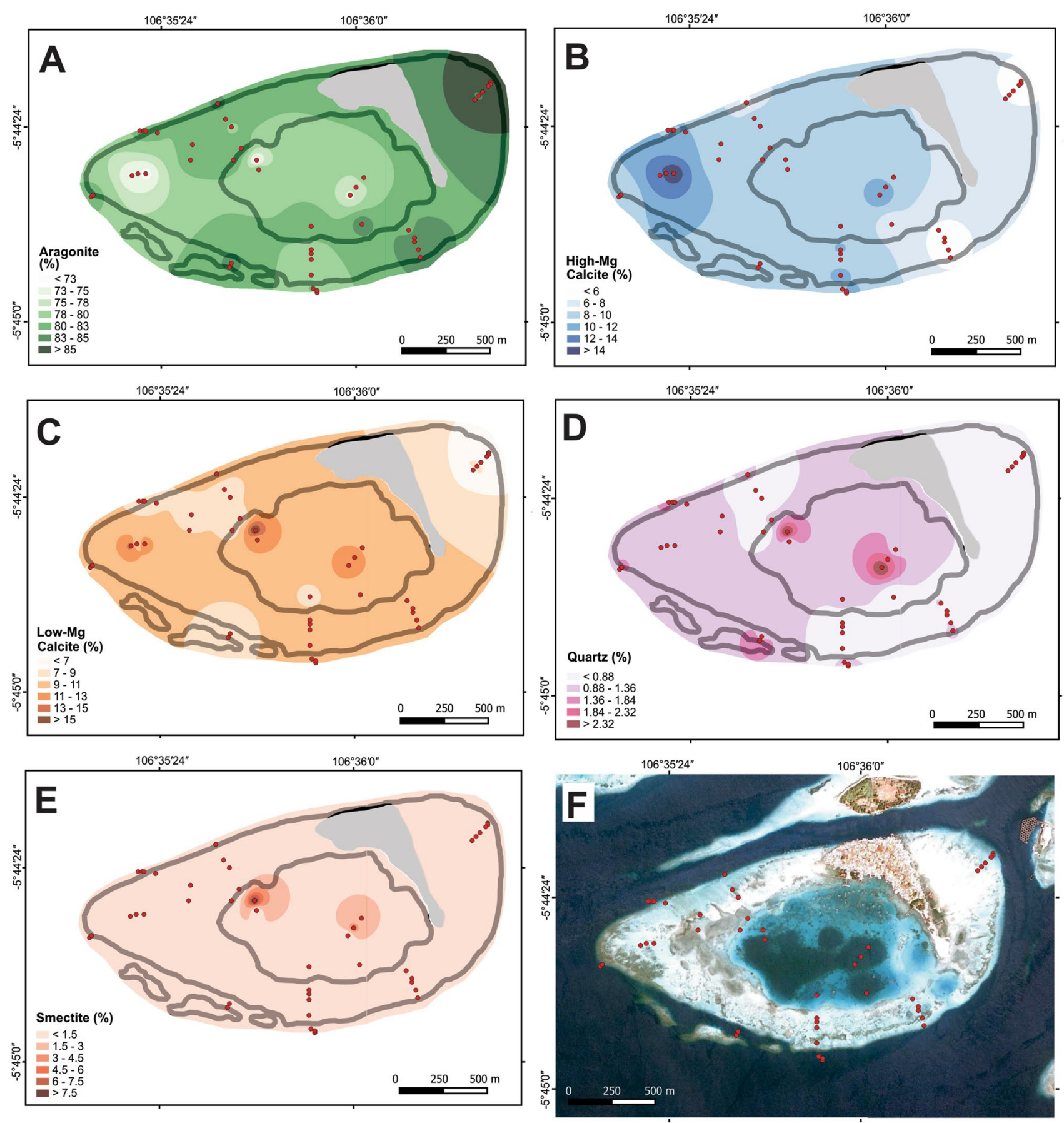

Fig. 4 Carbonate mineral distribution (normalized to only carbonate mineral phases) on the Panggang reef platform from 45 bulk sediment samples for a Aragonite. b High-Mg Calcite. c Low-Mg Calcite.

foraminifers are generally higher compared to the bulk samples but partly overlap with samples from the mollusk wackestone facies (Fig. 6). Carbon and oxygen isotope values of bulk sediment from Kepulauan Seribu show more positive value in the inner lagoon and more negative value in the reef front (Fig. 7).

Non-carbonate mineral distribution on Panggang reef platform from 45 bulk sediment samples for d Quartz. e Smectite. f Satellite image of Panggang reef platform and sampling spots

\section{Discussion}

\section{Spatial and compositional pattern in mineralogy}

The dominant mineral phase in Panggang is aragonite (Table 1). Its concentration varies little between facies 
Table 2 Mineralogy (\%) of five fine fraction $(<125 \mu \mathrm{m})$ samples, along with their respective bulk sample mineralogy

\begin{tabular}{|c|c|c|c|c|c|c|c|}
\hline \multicolumn{2}{|l|}{ Sample } & \multirow{2}{*}{$\begin{array}{l}\text { MPG 14C } \\
\text { C-M P }\end{array}$} & \multirow{2}{*}{$\begin{array}{l}\text { MPG 32D } \\
\text { M W }\end{array}$} & \multirow{2}{*}{$\begin{array}{l}\text { MPG 33D } \\
\text { M W }\end{array}$} & \multirow{2}{*}{$\begin{array}{l}\text { MPG 33G } \\
\text { M W }\end{array}$} & \multirow{2}{*}{$\begin{array}{l}\text { MPG 42L } \\
\text { C-M P }\end{array}$} & \multirow[t]{2}{*}{ Mean } \\
\hline Sedimentary facies & & & & & & & \\
\hline$<125 \mu \mathrm{m}$ & & $24 \%$ & $40 \%$ & $71 \%$ & $75 \%$ & $18 \%$ & \\
\hline \multirow[t]{4}{*}{ Carbonate* bulk mineralogy } & ARA & 79 & 83 & 77 & 75 & 81 & 79 \\
\hline & $\mathrm{HMC}$ & 11 & 8 & 11 & 12 & 9 & 10 \\
\hline & LMC & 9 & 8 & 11 & 13 & 9 & 10 \\
\hline & $\operatorname{Mg}(\%)$ & 13.0 & 14.0 & 11.7 & 12.7 & 14.0 & 13.1 \\
\hline \multirow[t]{4}{*}{ Carbonate* $<125 \mu \mathrm{m}$} & ARA & 74 & 76 & 73 & 71 & 74 & 73 \\
\hline & $\mathrm{HMC}$ & 14 & 13 & 14 & 15 & 13 & 14 \\
\hline & LMC & 12 & 9 & 13 & 12 & 10 & 11 \\
\hline & $\operatorname{Mg}(\%)$ & 15.3 & 11.7 & 14.0 & 13.3 & 14.0 & 13.7 \\
\hline \multirow[t]{5}{*}{ Bulk mineralogy } & ARA & 78 & 83 & 73 & 72 & 79 & 77 \\
\hline & HMC & 11 & 8 & 10 & 11 & 9 & 10 \\
\hline & LMC & 9 & 8 & 11 & 13 & 9 & 10 \\
\hline & Qz & 1 & 1 & 2 & 3 & 2 & 2 \\
\hline & $\mathrm{Sm}$ & 0 & 0 & 4 & 0 & 0 & 1 \\
\hline \multirow[t]{5}{*}{$<125 \mu \mathrm{m}$} & ARA & 66 & 62 & 64 & 64 & 62 & 64 \\
\hline & HMC & 13 & 11 & 13 & 13 & 11 & 12 \\
\hline & LMC & 11 & 8 & 12 & 11 & 8 & 10 \\
\hline & Qz & 4 & 4 & 3 & 2 & 4 & 3 \\
\hline & $\mathrm{Sm}$ & 7 & 14 & 9 & 8 & 11 & 10 \\
\hline
\end{tabular}

Carbonate* is mineralogy normalized to only carbonate mineral phases

Sed facies sedimentary facies, $C-M P$ coral-mollusc packstone, $M W$ mollusc wackestone, ARA aragonite, $H M C$ high magnesium calcite, $L M C$ low magnesium calcite, $Q z$ quartz, $S m$ smectite, $M g(\%)$ mole \% $\mathrm{MgCO}_{3}$ in $\mathrm{Mg}$ calcite

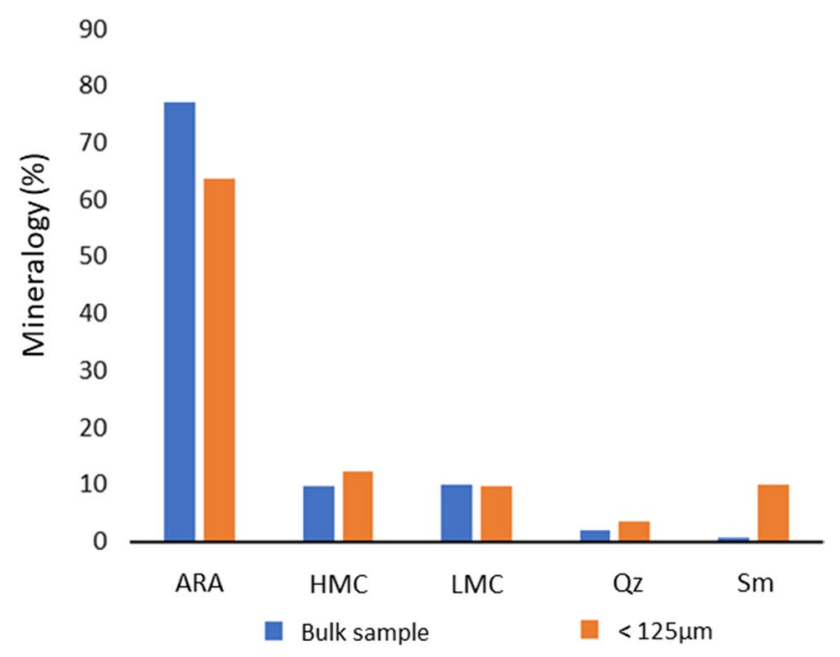

Fig. 5 Average mineralogy $(\%)$ of five fine fraction $(<125 \mu \mathrm{m})$ samples, along with their respective bulk sample mineralogy as indicated in Table 2

(Table 1, Fig. 3), with slightly increased values close to areas with dense coral cover on the reef front (Fig. 4). The aragonitic red algae genera Galaxaura and Liagora also thrive on the Kepulauan Seribu reef slope (Atmadja 1977), likely also contributing to the high aragonite concentrations. HMC and LMC occur in fairly similar amounts in all facies (Table 1, Fig. 3), with slightly increased values of LMC in the mollusc wackestone facies of the inner lagoon and some isolated points on the western reef flat (Fig. 4). Corals as the main aragonite producers are less abundant in this area, while less light dependent carbonate producers, such as molluscs and echinoderms, are more common (Table 1). The highest LMC content is found in the mollusc wackestone facies (Table 1), which is known to dominate in the inner lagoon where coral grainstone and coral packstone/grainstone facies are absent (Utami et al. 2018). High LMC content in the inner lagoon is likely due to the contribution from molluscs, the most important component in the mollusc wackestone facies (Table 1). Bivalves with calcitic or mixed aragonitecalcite shells in Kepulauan Seribu belong to the families Ostreidae (LMC), Pectinidae (LMC + ARA) and Pinnidae (LMC + ARA) (van der Meij et al. 2009; Ueda 2020). Five individual bivalve shells were measured using XRD. All of them have a mixed aragonite-calcite shell containing on average $90 \%$ aragonite and 10\% LMC. Locally, LMC is also abundant in the reef flat (Fig. 4), likely due to contributions from bivalves and larger benthic foraminifers (e.g. Amphistegina and Elphidium, Table 4) (Blackmon and Todd 1959) which are abundant in the coral grainstone 


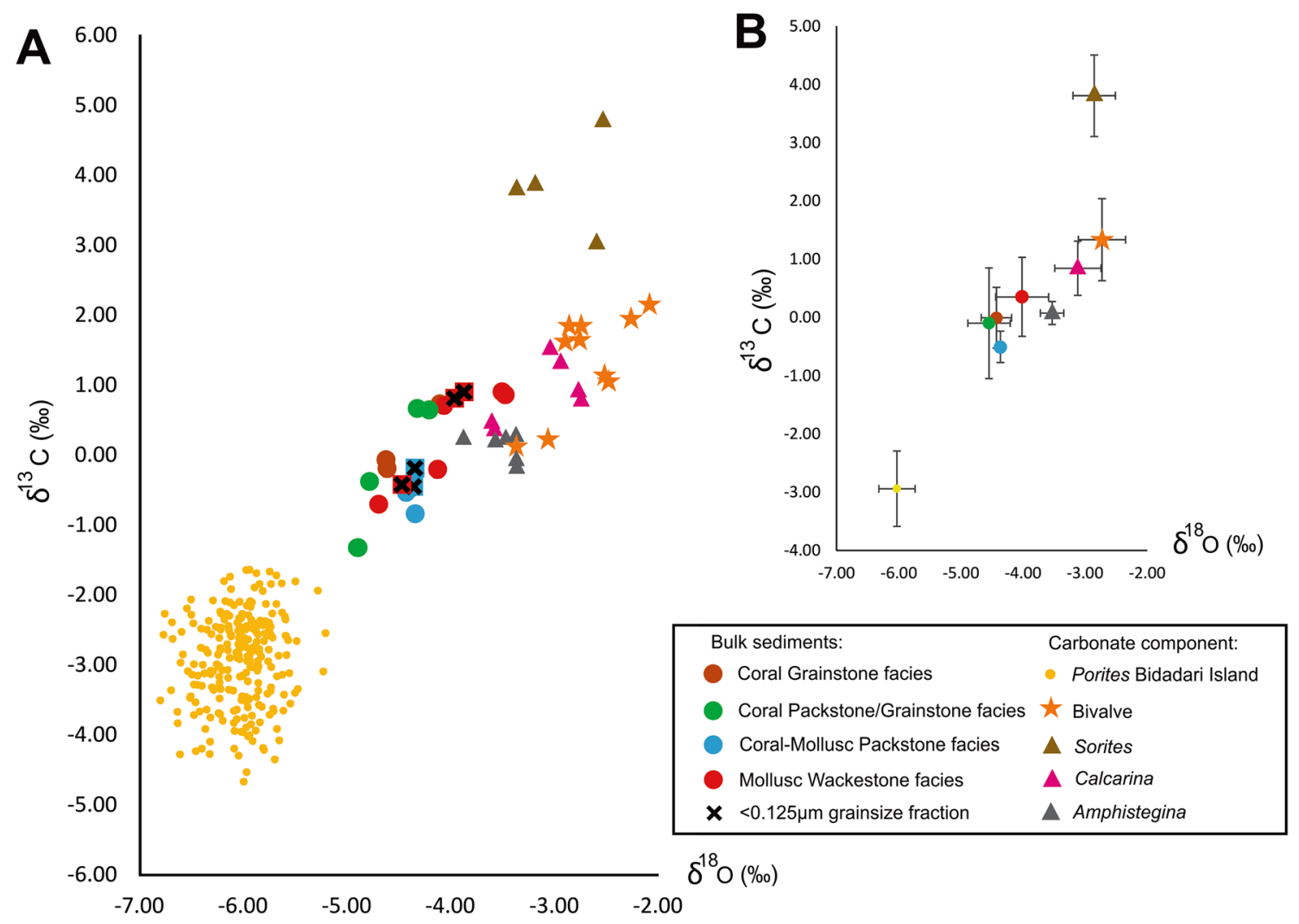

Fig. $6 \delta^{13} \mathrm{C}-\delta^{18} \mathrm{O}$ plot. a Sedimentary facies show considerable overlap in their isotopic composition. Also shown is the isotopic composition of bivalves and benthic foraminifers (rotaliids and miliolids) from the Panggang reef platform and a Porites coral from Bidadari

facies (Table 1). SEM analysis shows that calcareous nannoplankton, as a potential LMC source, is near absent in the sediment.

No clear correlation exists between HMC and individual biogenic grain types (Table 3 ). This is caused by the varied contribution of several different biota to the overall HMC content to the sediment. Red algae, such as Amphiroa, that are typically associated with sea grass in Kepulauan Seribu (Atmadja 1977), contribute HMC to the coral grainstone facies on the reef flat (Table 1). Echinoderms are more important in the deeper water coral-mollusc packstone facies and mollusc wackestone facies (Table 1) compared to other facies. Increased HMC contents in the inner lagoon (Fig. 4) can therefore be interpreted as a higher contribution from echinoderms. Mg content is generally higher in coralline algae compared to other organisms with HMC skeleton (Chave 1954). This is consistent with the observation that the lowest $\mathrm{Mg}$ contents in HMC are found in the mollusc wackestone facies where coralline algae are rare (Table 1, Fig. 3).

The mineralogy of five fine fraction $(<125 \mu \mathrm{m})$ subsamples from the coral-mollusc packstone and mollusc
Island, Kepulauan Seribu. All bivalves, Calcarina, Amphistegina, and one individual Sorites sample were split into two aliquots and measured as subsample. b Average values and standard deviation of measured isotopic composition for all facies and biota

wackestone facies was analyzed using XRD. The aragonite content in these fine fraction subsamples is $6 \%$ lower compared to their respective bulk samples (Table 2). In contrast, their HMC content is increased by $4 \%$ (Table 2). It has been proposed that fish can produce significant amounts of HMC mud (Salter et al. 2012). Most of the important ( $>5 \%$ abundance) fish families in the area of Kepulauan Seribu (Madduppa 2013) produce Mg-rich amorphous calcium carbonate. This carbonate phase commonly dissolves within hours and therefore is unlikely to be preserved as sediment (Salter et al. 2017). Only one family (Apogonidae) produces mud-sized HMC ellipsoids with Mg content of around 30-45\% (Salter et al. 2018). However, the typical crystal morphologies have not been observed during SEM investigations in our samples. It is, therefore, unlikely that fish-derived $\mathrm{Mg}$ calcite contributes significantly to the increased HMC values in the fine fraction. In contrast, SEM investigations confirm that the fine fraction is largely a product of skeletal breakdown (Fig. 2). Carbonate components that occur only in the mud to fine sand size $(<125 \mu \mathrm{m})$ fraction, such as tunicate spiculae and needles from Padina thalli, are exclusively aragonitic. Laboratory studies suggest 


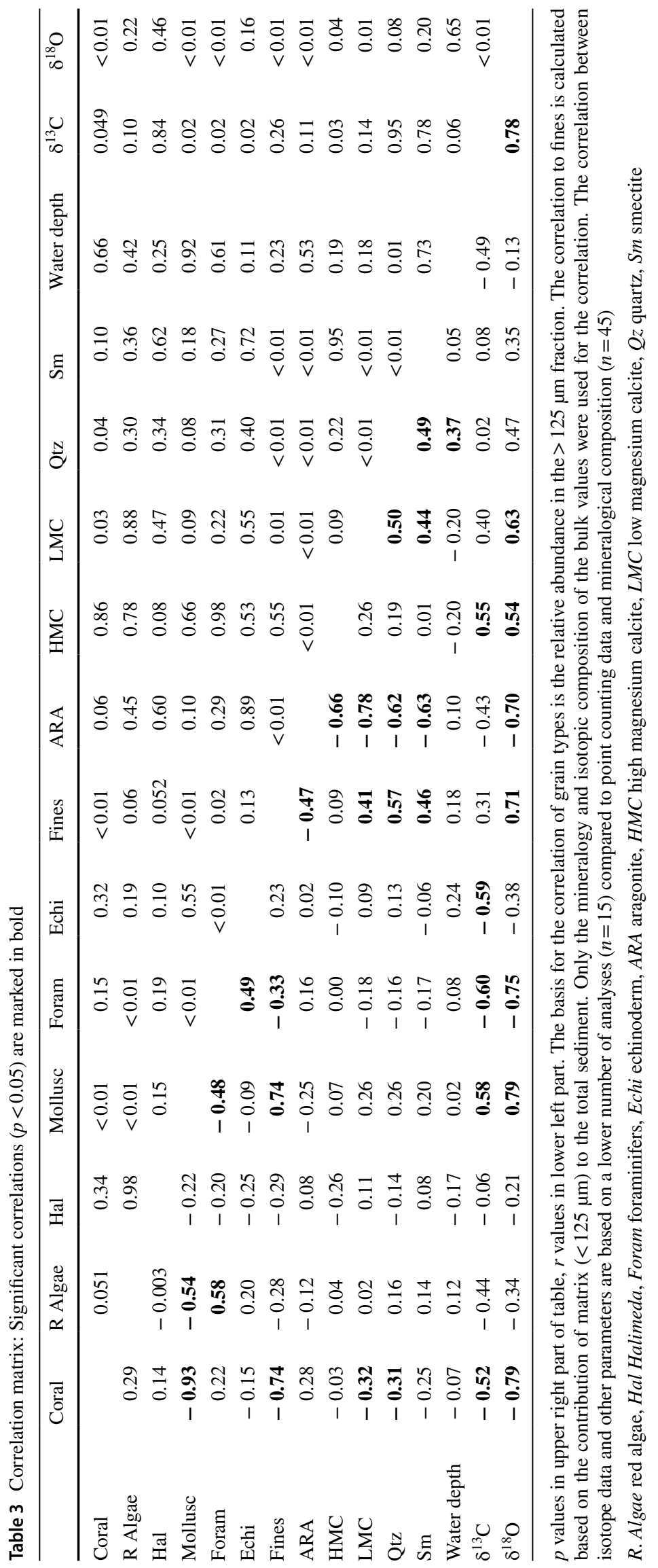



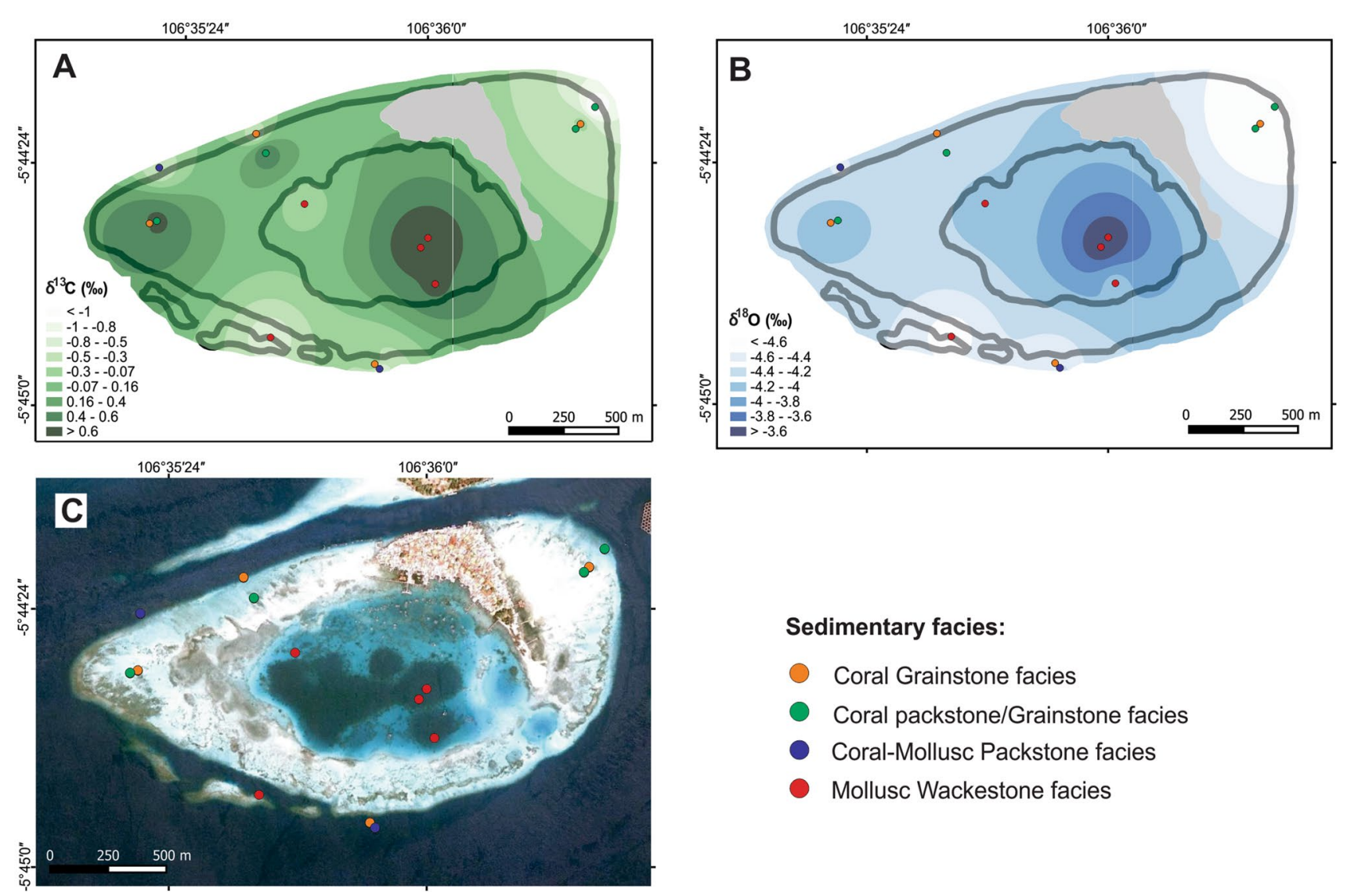

\section{Sedimentary facies:}

Coral Grainstone facies

- Coral packstone/Grainstone facies

- Coral-Mollusc Packstone facies

- Mollusc Wackestone facies

Fig. 7 Spatial composition map of carbon and oxygen isotopes of sediments on the Panggang reef platform. a $\delta^{13} \mathrm{C}(\% o)$ of 15 bulk sediment samples. $\mathbf{b} \delta^{18} \mathrm{O}(\%)$ of 15 bulk sediment samples. c Satellite image of Panggang reef platform and sampling spots

Table 4 Faunal elements in Kepulauan Seribu (Atmadja 1977; Renema 2008; van der Meij et al. 2009; Park et al. 2010; Ueda 2020) and their mineralogy

\begin{tabular}{|c|c|c|c|c|c|}
\hline & Red algae (Genus) & $\begin{array}{l}\text { Brown } \\
\text { algae } \\
\text { (Genus) }\end{array}$ & Green algae (Genus) & Bivalve (Family) & $\begin{array}{l}\text { Benthic } \\
\text { foraminifers } \\
\text { (Genus) }\end{array}$ \\
\hline Aragonite & $\begin{array}{l}\text { Liagora } \\
\text { Galaxaura }\end{array}$ & Padina & Halimeda & All other families & \\
\hline HMC & $\begin{array}{l}\text { Amphiroa } \\
\text { Goniolithon } \\
\text { Jania } \\
\text { Lithothamnion }\end{array}$ & & & & $\begin{array}{l}\text { Amphisorus } \\
\text { Borelis } \\
\text { Calcarina } \\
\text { Dendritina } \\
\text { Heterostegina } \\
\text { Laevipeneroplis } \\
\text { Monalysidium } \\
\text { Operculina } \\
\text { Parasorites } \\
\text { Peneroplis } \\
\text { Sorites }\end{array}$ \\
\hline LMC & & & & $\begin{array}{l}\text { Pectinidae (+ ARA) } \\
\text { Ostreidae } \\
\text { Pinnidae (+ ARA) }\end{array}$ & $\begin{array}{l}\text { Amphistegina } \\
\text { Elphidium }\end{array}$ \\
\hline
\end{tabular}


that abrasion rates of corals are much slower compared to dominant HMC components, such as coralline algae and echinoderms (Milliman et al. 1974). Increased HMC content in the fine fraction (Table 2) therefore could be related to preferential breakdown of HMC components. However, it remains unclear in how far these laboratory results can be applied to natural settings. Quantitative data on the composition of different grains size fractions from isolated carbonate platforms of Belize were presented by Gischler and Zingeler (2002). Our calculations based on this data indicate that coral fragments are actually increased in abundance relative to echinoderm and red algae fragments in the fine $(<125 \mu \mathrm{m})$ fraction as compared to the larger grain size fraction. This is opposite to what would be expected by the laboratory results on mechanical abrasion (Milliman et al. 1974), possibly indicating that other processes, such as bioerosion, are more important in reef settings. The preferential abrasion of HMC components therefore seems not to be the reason for the increased HMC content in the fine fraction. A known source of mud-sized HMC are red algae growing on sea grass (Land 1970; Perry et al. 2019). Patches of sea grasses are common on the Seribu islands and are associated with reduced grain sizes in the sediment, likely due to their baffling effect (Utami et al. 2018). They also might contribute to the increased HMC contents in the fine fraction. However, a comparison of the mineralogical composition between locations with dense and sparse sea grass cover on the sand apron of Panggang does not show a significant difference with respect to HMC content (Mann-Whitney $U$ test, $p=0.91$ ). Due to the abundance of sea grass, our dataset does not include samples from locations without sea grass.

Alternatively, micritization in northern Belize increases the HMC content of skeletal grains, which later are preferentially abraded and contribute to carbonate muds. Cementation in micro-bioerosion traces is an important mechanism for micritization (Reid and Macintyre 2000). High Mg calcite cement has been observed, besides other mineral phases, in endolithic microborings in corals (Schroeder 1972). Bioerosion and/or micritization are ubiquitous in reefs affected by terrestrial runoff or upwelling in SE Asia (Tomascik et al. 1997; Wilson 2012; Madden and Wilson 2012) including the Seribu Islands (Fig. 2) (Park et al. 1992, 2010). Both processes are most intense at the outer surface of carbonate grains. The higher surface-to-volume ratio of smaller grains could therefore lead to stronger alteration of its mineralogy compared to larger grains. Micritization and bioerosion could therefore have contributed to the increased HMC content in the fine fraction of Panggang (Table 2).

Small amounts of siliciclastic minerals are found in Kepulauan Seribu (Table 1). Quartz content increases with water depth (Table 3), in the inner lagoon and reef front. Quartz and smectite are strongly concentrated in the fine fraction (Table 2), indicating that quartz grains will settle from suspension in low-energy environments but are easily winnowed by waves and currents in high-energy environments. Smectite occurs only in $>6 \mathrm{~m}$ water depth within the inner lagoon (Fig. 4), where it likely settles below the wave base. The fact that siliciclastic minerals are found in almost all samples (Fig. 4) shows that Panggang is influenced by terrestrial runoff (Fig. 1). A possible source for the siliciclastics could be Sumatra, since Kepulauan Seribu is relatively isolated from a direct influence from Java and Kalimantan by the regional current system (Tomascik et al. 1997; Jordan 1998). Partially due to this siliciclastic influence, the depth of abundant coral growth in Kepulauan Seribu (0-18 m, Jordan 1998) is typical for equatorial carbonates in SE Asia, but very shallow compared to other regions $(0-100 \mathrm{~m})$ with clearer water and lower nutrient input (Wilson 2008).

\section{Spatial patterns in stable isotope composition of sediment}

Delineating facies based on their $\delta^{13} \mathrm{C}$ and $\delta^{18} \mathrm{O}$ values is not possible due to a lack of a significance difference between carbonate facies (Kruskal-Wallis test, $p=0.17$ and $p=0.15$, respectively). However, the average stable isotope values of the coral grainstone facies $\left(\delta^{13} \mathrm{C}=0.0, \delta^{18} \mathrm{O}=-4.4\right)$ is lower compared to the mollusc wackestone facies $\left(\delta^{13} \mathrm{C}=0.4\right.$, $\delta^{18} \mathrm{O}=-4.0$ ), suggesting some facies control (Fig. 6). Coral abundance shows a significantly negative correlation to $\delta^{13} \mathrm{C}$ and $\delta^{18} \mathrm{O}$ values (Table 3 ). This results from a strong kinetic control on isotope fractionation in corals (McConnaughey 2003). Coral skeletons therefore show a depletion of heavy isotopes and consequently a strong offset from equilibrium values towards more negative isotope ratios (Fig. 6). Corals exert a strong influence on the bulk isotope composition, since they are the predominant skeletal material and major aragonite producer (Fig. 6). Marine mollusc shells, as the second most important sedimentary component (Table 3), do not show kinetic effects in their isotopic composition (McConnaughey and Gillikin 2008). Their $\delta^{18} \mathrm{O}$ values are often close to equilibrium values (Grossman and $\mathrm{Ku} 1986$ ) and therefore more positive compared to corals (Fig. 6) (Aharon 1991). Carbon isotope signatures in molluscs are complex, with near equilibrium values e.g. in giant clams (Aharon 1991) but often several \%o lighter due to metabolic carbon contribution (McConnaughey and Gillikin 2008). In reefal carbonates, molluscs are typically less depleted in ${ }^{13} \mathrm{C}$ compared to cooccurring corals (Fig. 6) (González and Lohmann 1985). This results in a positive (negative) correlation (Table 3 ) between oxygen and carbon isotopes and molluscs (corals). Higher stable isotope values in the inner lagoon and sand apron of Panggang (Fig. 7) result from the increased abundance of molluscs in mollusc wackestone and coral packstone/grainstone facies (Table 1) and coincides with the overall lowest aragonite value (Fig. 4). The most 
negative $\delta^{13} \mathrm{C}$ and $\delta^{18} \mathrm{O}$ values occur at the reef front in coral grainstone and coral packstone/grainstone facies where coral cover is densest (Fig. 7). However, the compositional differences between individual facies types (Table 1) are not strong enough to result in separate isotope fields for each facies (Fig. 6).

The most important group of purely calcitic components are benthic foraminifers. Many shallow water benthic foraminifers from reefal environments precipitate their skeleton close to oxygen isotope equilibrium $( \pm 1 \%$ ) (Saraswati et al. 2004; Maeda et al. 2017), although slightly stronger depletion of ${ }^{18} \mathrm{O}$ was observed as well (Wefer and Berger 1991). Carbon isotopes typically are lighter compared to equilibrium values with common ${ }^{13} \mathrm{C}$ depletion on the order of $1-3 \%$ or most miliolids and $2-5 \%$ or for rotaliids (Wefer et al. 1981; Saraswati et al. 2004). This is consistent with lower $\delta^{13} \mathrm{C}$ values in rotaliids (Calcarina, Amphistegina) compared to miliolids (Sorites) in the study area (Fig. 6). Benthic foraminifers from reefal environments therefore are characterized by generally more positive stable isotope values compared to cooccurring corals (Fig. 6), but can show partial overlap in their $\delta^{13} \mathrm{C}$ ranges (González and Lohmann 1985; Gischler et al. 2012), especially if rotaliids are abundant. The observed negative correlation between aragonite content and stable isotope values (Table 3 ) likely results from this isotopic difference between corals and benthic foraminifers as the main aragonite and calcite producers, respectively. The fact that some molluscs contribute calcite to the sediment likely enhances this effect.

The positive correlation between stable isotopes and fines is a spurious relationship (Table 3), resulting from the strong positive (negative) correlation with molluscs (corals). This is supported by the observation that the fine fraction samples show no consistent isotopic difference to the bulk samples (Table 3). This similarity indicates that the fine fraction is genetically related to the coarse fraction and is formed by skeletal breakdown.

\section{Comparison with other carbonate systems}

To facilitate the comparison of mineralogical and stable isotope signatures between humid equatorial, arid (sub) tropical, and temperate carbonate systems we have grouped them geographically (Figs. 8 and 10). Carbonates from each geographical group share common characteristics and are deposited under similar environmental conditions (Fig. 9, Table 5). Carbonate systems from the tropical western Atlantic (TWA) and Persian Gulf represent mostly (sub)tropical carbonates (sensu Wilson 2002, 2012) characterized by at least seasonally arid conditions. These carbonates often contain facies with non-skeletal grains and are deposited in normal marine to hypersaline waters (Table 5). Exceptions are Florida Bay and Belize, which are characterized by riverine input leading to strong gradients in salinity ranging from brackish to hypersaline and absence or low abundance of non-skeletal grains. The carbonates from the Indo-Pacific Warm Pool (IPWP) (Figs. 8, 9, 10, Table 5) are deposited on isolated carbonate platforms under the highest average temperatures $\left(>28^{\circ} \mathrm{C}\right)$ and high seasonal precipitation, but outside the direct influence of river runoff. Non-skeletal grains are uncommon. High latitude systems (Figs. 8, 9, 10, Table 5) are typical temperate water Heterozoan carbonates (Wilson 2012).

The $\delta^{13} \mathrm{C}$ signature of carbonates from Kepulauan Seribu is considerably more negative compared to most other platform and reef systems (Fig. 8). The carbon isotopic composition of marine carbonates is mainly influenced by the $\delta^{13} \mathrm{C}$ of the dissolved inorganic carbon (DIC) in water (Smith and Kroopnick 1981), the mineralogy (Rubinson and Clayton 1969; Romanek et al. 1992) and so called "vital effects" in carbonate secreting organisms (e.g. kinetic and metabolic effects) (McConnaughey 2003; McConnaughey and Gillikin 2008). Because of these vital effects skeletal carbonates are typically depleted in $\delta^{13} \mathrm{C}$ compared to inorganically precipitated carbonates from the same environment (Swart et al. 2009; Gischler et al. 2012). Non-skeletal grains and inorganically precipitated muds are much more common in modern platforms and reefs from the tropical, western Atlantic (TWA) and Persian Gulf compared to carbonate systems from the Indo-Pacific Warm Pool or New Zealand (Table 5) (Milliman et al. 1974; Gischler 2011; Gallagher et al. 2018). Most carbonates from the TWA and Persian Gulf therefore show broader $\delta^{13} \mathrm{C}$ ranges encompassing more positive $\delta^{13} \mathrm{C}$ values (Fig. 8).

Due to mineralogical effects, inorganic aragonite is enriched in $\delta^{13} \mathrm{C}$ by about $1.8 \%$ compared to coprecipitated calcite (Rubinson and Clayton 1969; Romanek et al. 1992). This mineralogical effect should favor a positive correlation between aragonite content and $\delta^{13} \mathrm{C}$. However, the actual relation depends on the source and therefore isotopic signature of the aragonite. Aragonitic non-skeletal grains and green algae (Fig. 8) are characterized by more positive $\delta^{13} \mathrm{C}$ values compared to most calcitic skeletal grains, resulting in a positive correlation between both parameters (Swart et al. 2009; Gischler et al. 2012). Corals on the other hand are more depleted in $\delta^{13} \mathrm{C}$ compared to most calcite secreting organisms (Fig. 6), which explains the negative correlation between aragonite and $\delta^{13} \mathrm{C}$ in the coral dominated Kepulauan Seribu (Table 3) and the lower $\delta^{13} \mathrm{C}$ compared to the relatively calcite-rich cool water carbonates (Fig. 8). However, the $\delta^{13} \mathrm{C}$ signature of carbonate from Kepulauan Seribu is also more negative compared to most other coral dominated reef facies from the IPWP (Fig. 8).

Carbon isotope data from a Porites coral from Bidadari Island (Fig. 1) in the Java Sea, is on average more depleted compared to Porites corals from the Seychelles and Chagos 


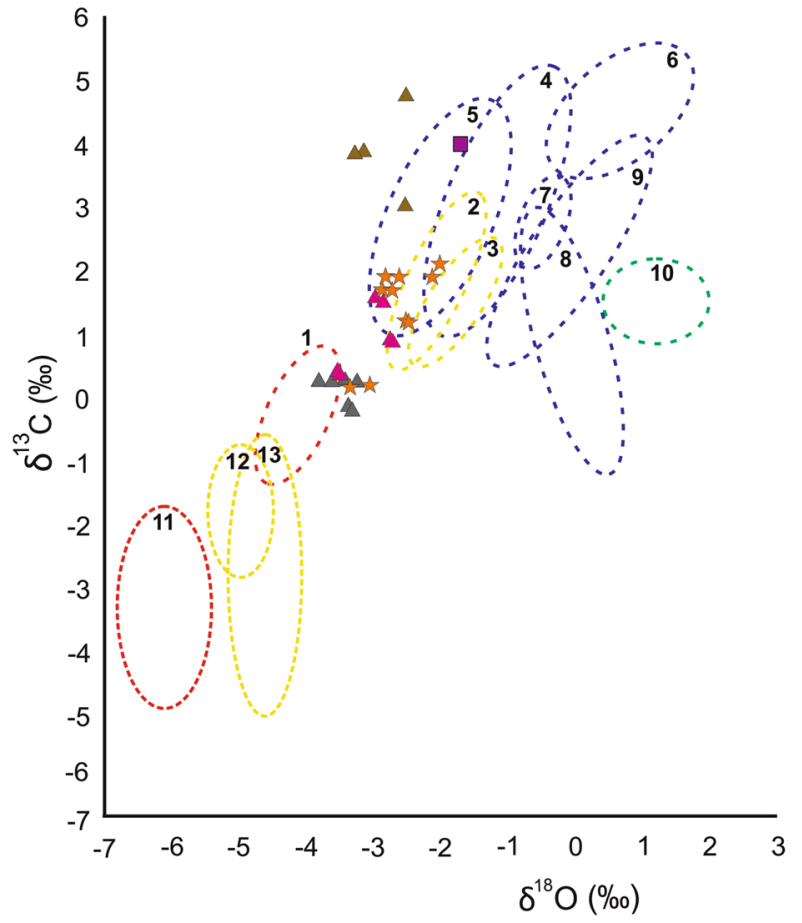

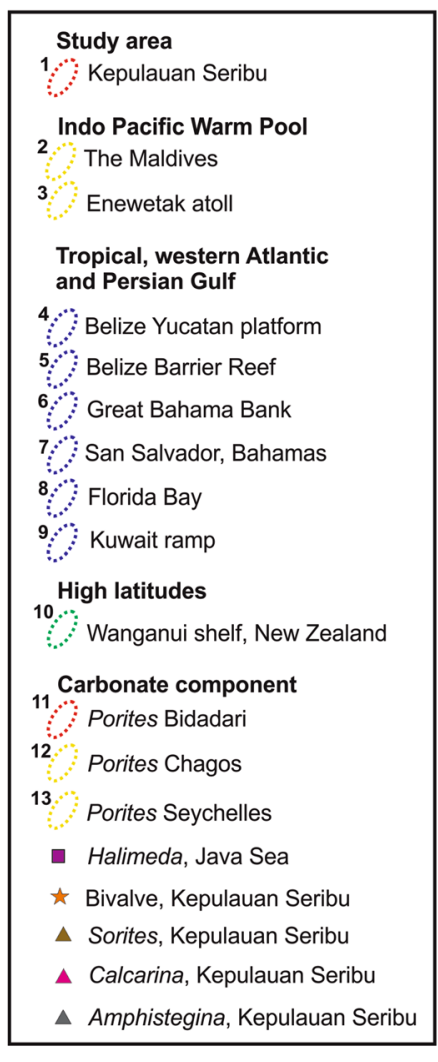

Fig. 8 Cross-plot of $\delta^{13} \mathrm{C}-\delta^{18} \mathrm{O}$ ranges of sediments from Panggang reef platform, Kepulauan Seribu. Also shown are stable isotope ranges of sediments from the Indo-Pacific Warm Pool (IPWP): Maldives (Gischler 2006), Enewetak Atoll (Weber and Schmalz 1968); Tropical, western Atlantic (TWA) and Persian Gulf: Belize Yucatan platform and Belize Barrier Reef (Gischler and Lomando 1999; Gischler et al. 2012), Great Bahama Bank (Swart et al. 2009), San Salvador Island, Bahamas (Husinec et al. 2019), Florida Bay (Swart et al. 1989; Andrews 1991), Kuwait ramp (Gischler and Lomando

both of which are located within the IPWP (Fig. 8) (Pfeiffer et al. 2004; Pfeiffer and Dullo 2006; Cahyarini et al. 2016). It is unlikely that this difference is solely due to kinetic related offsets, since all three coral colonies show similar growth rates (Pfeiffer et al. 2004; Pfeiffer and Dullo 2006; Cahyarini et al. 2016). More negative $\delta^{13} \mathrm{C}$ values of the Porites colony from Bidadari Island are more likely due to the influence of river run off. Corals have the potential to record land-ocean carbon transfer because they draw on dissolved inorganic carbon (DIC) for calcification. The $\delta^{13} \mathrm{C}$ of DIC in coastal water is influenced by the $\delta^{13} \mathrm{C}$ signature from adjacent rivers (Moyer and Grottoli 2011). Bidadari Island is located in the Java Sea (Fig. 1) and in close proximity to three major rivers in the Greater Jakarta Area (Farhan and Lim 2012). Estuaries in SE Asia show low $\delta^{13} C_{\text {DIC }}$ values due to the contribution of ${ }^{12} \mathrm{C}$ from riverside mangroves (Miyajima et al. 2009). The low $\delta^{13} \mathrm{C}$ of the coral skeleton in Kepulauan Seribu therefore likely reflects the enrichment in ${ }^{12} \mathrm{C}$
2005), and an example from high latitudes; Wanganui shelf, New Zealand (Gillespie and Nelson 1997). For comparison the isotopes ranges of faunal elements are shown: Porites coral from Bidadari Island, Kepulauan Seribu (Cahyarini et al. 2016), Porites corals from Seychelles and Chagos (Pfeiffer et al. 2004; Pfeiffer and Dullo 2006), Halimeda bioherm, eastern Java Sea (Aharon 1991), bivalves and benthic foraminifers from Panggang reef platform. Location of Bidadari Island is shown in Fig. 1

of ambient seawater due to the input of riverine DIC to the Java Sea.

To a somewhat lesser extent, light intensity (photosynthesis) also has been shown to influence the value of skeletal $\delta^{13} \mathrm{C}$ in corals (Moyer and Grottoli 2011). Corals are usually depleted in ${ }^{13} \mathrm{C}$ relative to ambient seawater as a result of kinetic and metabolic fractionation (Swart 1983; McConnaughey 1989; Allison et al. 1996; Grottoli and Wellington 1999). Environmental variables that influence coral metabolism should therefore also affect $\delta^{13} \mathrm{C}$ levels in coral skeletons (Grottoli 2002). Under low light conditions photosynthesis decreases and metabolic fractionation increases with the consequence of decreased skeletal $\delta^{13} \mathrm{C}$ (Grottoli 2002). Sediment input from rivers into the Java Sea potentially enhances turbidity in the semi-enclosed basin, leading to a reduction of light intensity and photosynthesis thus resulting in reduced skeletal $\delta^{13} \mathrm{C}$ values. This would be consistent with the relatively shallow depth of reef growth 

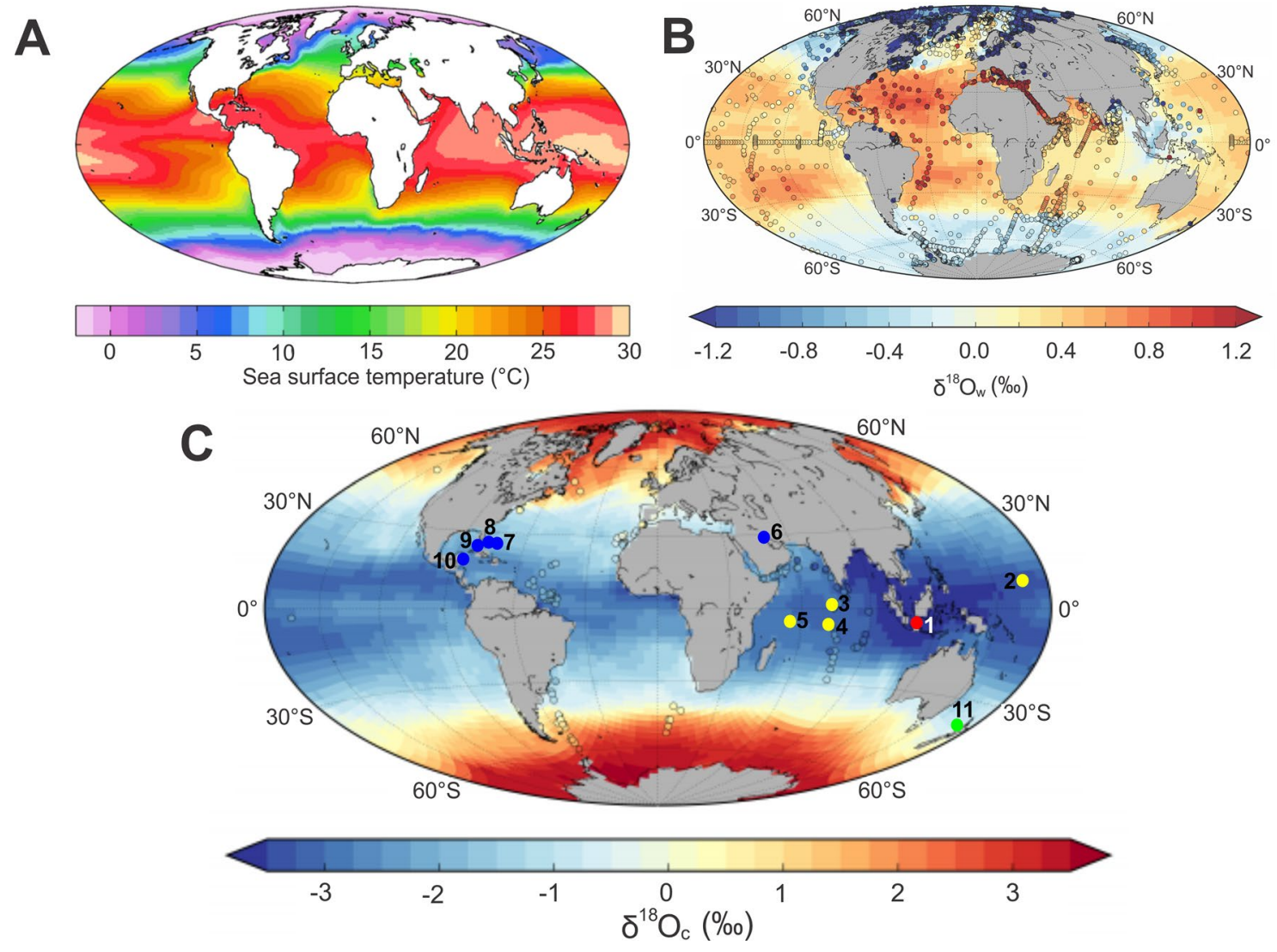

Fig. 9 Main controlling factors for oxygen isotope composition of carbonate minerals are temperature and $\delta^{18} \mathrm{O}$ of water (a). Annual mean sea surface temperature (World Ocean Atlas 2009; http://www. nodc.noaa.gov/OC5/WOA09/pr_woa09.html). b Global annual mean surface (upper $50 \mathrm{~m}$ ) $\delta^{18} \mathrm{O}_{\mathrm{w}}$ distribution simulated by a general circulation model (MITgcm) in comparison to the observational isotope data (colored symbols-Schmidt et al. 1999) for the global ocean

(Jordan 1998) and the presence of siliciclastic minerals in sediment samples below the wave base (Fig. 4) in the study area. Turbidity can also be produced by algae blooms caused by increased nutrient input either through river water or untreated sewage from populated islands (Baum et al. 2015). Additionally, higher nutrient availability could influence the $\delta^{13} \mathrm{C}$ of coral skeletons by an increase in the heterotrophic feeding rate or an increase in the photosynthesis rate related to higher zooxanthellate concentrations (Grottoli 2002). However, these processes have opposing effect on the $\delta^{13} \mathrm{C}$ of coral skeletons. The net effect therefore will depend on the relative magnitudes of these various influences but is expected to be small (Heikoop et al. 2000).

The largest single anthropogenic influence on the isotope signature of recent corals likely is caused by the input of anthropogenic $\mathrm{CO}_{2}$ to the global surface ocean. The accelerated admixture of fossil fuel derived $\mathrm{CO}_{2}$ leads to a shift towards lower $\delta^{13} \mathrm{C}$ values in atmospheric $\mathrm{CO}_{2}$, the so called Suess effect (Keeling 1979). This Suess effect is often
(Völpel et al. 2017). c Distribution of modelled annual mean sea surface (upper $50 \mathrm{~m}) \delta^{18} \mathrm{O}$ in calcite $\left(\delta^{18} \mathrm{O}_{\mathrm{c}}\right)$ compared to $\delta^{18} \mathrm{O}_{\mathrm{c}}$ values measured on planktonic foraminifers from plankton tows (Völpel et al. 2017). Location of carbonate sites: 1. Study area in Kepulauan Seribu, 2. Enewetak, 3. The Maldives, 4. Chagos, 5. Seychelles, 6. Kuwait ramp, 7. San Salvador, Bahamas, 8. Great Bahama Bank, 9. Florida Bay, 10. Belize, 11. Wanganui shelf, New Zealand

recorded in declining coral skeleton $\delta^{13} \mathrm{C}$ values over the twentieth century (Swart et al. 2010). Linsley et al. (2019) showed that the Suess effect can shift skeletal $\delta^{13} \mathrm{C}$ in corals by more than $1 \%$ o since the 1950 s. The carbon isotope composition of corals in Fig. 8, which are largely derived from the twentieth century, is therefore likely depleted relative to bulk sediments or sedimentary grains of mixed and/ or unknown age.

Florida Bay is the only location that shows a nearly complete overlap but broader total range in $\delta^{13} \mathrm{C}$ values compared to the sediments from Kepulauan Seribu (Fig. 8). In contrast to many other areas in the TWA, non-skeletal grains and inorganic mud are lacking in Florida Bay (Table 5). Average $\delta^{13} C_{\text {DIC }}$ of surface waters in Florida Bay is lowest in areas influenced by isotopically depleted river runoff from the Everglades, while the $\delta^{13} \mathrm{C}$ variability in other areas is controlled by remineralization of marine organic matter (Swart and Price 2002). Similar to Kepulauan Seribu, the lowest values in $\delta^{13} \mathrm{C}$ of carbonates deposited in Florida Bay 
Table 5 Location and basic environmental and sedimentological data for carbonate systems used for comparison in Figs. 8 and 10

\begin{tabular}{|c|c|c|c|c|c|c|c|}
\hline Location & & $\operatorname{SST}\left({ }^{\circ} \mathrm{C}\right)$ & SSS $(\% 0)$ & $\delta 13 \mathrm{C}(\% \circ)$ & $\delta 180(\%)$ & Non-skeletal grains & Source \\
\hline $\begin{array}{l}\text { Panggang, Kepu- } \\
\text { lauan Seribu }\end{array}$ & $5^{\circ} 44^{\prime} \mathrm{S}, 106^{\circ} 36^{\prime} \mathrm{E}$ & $28-30$ & $30-34$ & $0.02 \pm 0.7$ & $-4.27 \pm 0.4$ & Very rare & This study \\
\hline $\begin{array}{l}\text { Rasdhoo \& Ari } \\
\text { atoll, Maldives }\end{array}$ & $\begin{array}{l}3^{\circ} 37^{\prime}-4^{\circ} 17^{\prime} \mathrm{N}, \\
72^{\circ} 54^{\prime}-72^{\circ} 58^{\prime} \mathrm{E}\end{array}$ & $28-30$ & $34.4-35.4$ & $1.56 \pm 0.58$ & $-2.06 \pm 0.83$ & Very rare & Gischler (2006) \\
\hline Enewetak & $\begin{array}{l}11^{\circ} 25^{\prime} \mathrm{N}, 162^{\circ} \\
20^{\prime} \mathrm{E}\end{array}$ & $28-32$ & $34-35$ & $1.75 \pm 0.55$ & $-1.90 \pm 0.42$ & None & $\begin{array}{l}\text { Weber and Schmalz } \\
\text { (1968) }\end{array}$ \\
\hline $\begin{array}{l}\text { Honduras, Car- } \\
\text { ribean oceanic } \\
\text { barrier reef }\end{array}$ & $\begin{array}{l}16^{\circ} 23^{\prime} \mathrm{N}, 86^{\circ} 25^{\prime} \\
\mathrm{W}\end{array}$ & $29-31$ & $36-37$ & N/A & N/A & $\begin{array}{l}\text { Peloids common, } \\
\text { ooids rare }\end{array}$ & $\begin{array}{l}\text { Schmitt and Gischler } \\
\text { (2017) }\end{array}$ \\
\hline Belize Barrier Reef & $\begin{array}{l}16^{\circ} 30-18 \mathrm{~N}, 88^{\circ} \\
\mathrm{W}\end{array}$ & $24-27$ & $30-35$ & N/A & N/A & Rare & Gischler et al. (2013) \\
\hline $\begin{array}{l}\text { Belize-Yucatan } \\
\text { Platform (Glov- } \\
\text { ers, Lighthouse, } \\
\text { Turneffe) }\end{array}$ & $\begin{array}{l}16^{\circ} 44^{\prime}-17^{\circ} 18^{\prime} \\
\mathrm{N}, 87^{\circ} 32^{\prime}-87^{\circ} \\
48^{\prime} \mathrm{W}\end{array}$ & $21.7-31.8$ & $34.2-42.5$ & N/A & N/A & Rare to moderate & Gischler et al. (2012) \\
\hline $\begin{array}{l}\text { Belize northern } \\
\text { shelf }\end{array}$ & $\begin{array}{l}17^{\circ} 45^{\prime}-18^{\circ} \mathrm{N} \\
88^{\circ} \mathrm{W}\end{array}$ & $25.5-28.5$ & $30-34$ & N/A & N/A & Rare & Gischler et al. (2013) \\
\hline $\begin{array}{l}\text { Belize southern } \\
\text { shelf }\end{array}$ & $16^{\circ}-17^{\circ} \mathrm{N}, 88^{\circ} \mathrm{W}$ & & & N/A & N/A & & $\begin{array}{l}\text { Weber and Schmalz } \\
\text { (1968) }\end{array}$ \\
\hline Great Bahama Bank & $\begin{array}{l}23^{\circ}-26^{\circ} \mathrm{N}, 77^{\circ} \\
30^{\prime}-79^{\circ} 30^{\prime} \mathrm{W}\end{array}$ & $18.5-28.5$ & $36-46$ & $4.8 \pm 0.3$ & $0.4 \pm 0.4$ & Abundant & $\begin{array}{l}\text { Reijmer et al. (2009); } \\
\text { Swart et al. (2009) }\end{array}$ \\
\hline $\begin{array}{l}\text { San Salvador Island, } \\
\text { Bahamas }\end{array}$ & $\begin{array}{l}24^{\circ} 05^{\prime} \mathrm{N}, 74^{\circ} 26^{\prime} \\
\mathrm{W}\end{array}$ & $24-30$ & 35 & 2.2 & -0.9 & $\begin{array}{l}\text { Moderate to abun- } \\
\text { dant }\end{array}$ & Husinec et al. (2019) \\
\hline Florida Bay & $\begin{array}{l}25^{\circ} 01^{\prime} \mathrm{N}, 80^{\circ} 34^{\prime} \\
\mathrm{W}\end{array}$ & $15-40$ & $10-40$ & N/A & N/A & None & $\begin{array}{l}\text { Ginsburg (1956); } \\
\text { Swart et al. (1989); } \\
\text { Andrews (1991) }\end{array}$ \\
\hline Kuwait ramp & $\begin{array}{l}28^{\circ} 30^{\prime}-29^{\circ} 15^{\prime} \mathrm{N}, \\
18^{\circ} 15^{\prime}-18^{\circ} 45^{\prime} \mathrm{E}\end{array}$ & $13-32$ & $38.5-42.5$ & N/A & N/A & Abundant & $\begin{array}{l}\text { Gischler and } \\
\text { Lomando (2005) }\end{array}$ \\
\hline $\begin{array}{l}\text { Spencer Gulf, South } \\
\text { Australia }\end{array}$ & $\begin{array}{l}33^{\circ}-35^{\circ} \mathrm{S} \\
136^{\circ}-138^{\circ} \mathrm{E}\end{array}$ & $10-28$ & $36-47$ & N/A & N/A & None & $\begin{array}{l}\text { O'Connell and James } \\
\text { (2015) }\end{array}$ \\
\hline $\begin{array}{l}\text { Lacepede Shelf (LS) } \\
\text { and Great Austral- } \\
\text { ian Bight (GAB), } \\
\text { Southern Australia }\end{array}$ & $\begin{array}{l}\mathrm{LS}: 35^{\circ} 30^{\prime}-38^{\circ} \mathrm{S}, \\
137^{\circ}-140^{\circ} \mathrm{E} \\
\mathrm{GAB}: 33^{\circ} 15-35^{\circ} \\
\mathrm{S}, 124^{\circ}-134^{\circ} \mathrm{E}\end{array}$ & $\begin{array}{l}\text { LS: }<14-20 \\
\text { GAB: } \\
17-22\end{array}$ & $35.9-36.4$ & N/A & N/A & None & $\begin{array}{l}\text { O'Connell and James } \\
\text { (2015) }\end{array}$ \\
\hline $\begin{array}{l}\text { Wanganui Shelf, } \\
\text { New Zealand }\end{array}$ & $40^{\circ} \mathrm{S}, 175^{\circ} \mathrm{E}$ & ca. 15 & $34-35$ & N/A & N/A & None & $\begin{array}{l}\text { Gillespie and Nelson } \\
\text { (1997) }\end{array}$ \\
\hline
\end{tabular}

$* \mathrm{~N} / \mathrm{A}=$ average and standard deviation data not available

seem to be a result of isotopically depleted river runoff and a lack of inorganic carbonate precipitation.

Since the pioneering work by Urey (1947), the $\delta^{18} \mathrm{O}$ values of carbonate minerals are known to be controlled by temperature of formation. Other controlling factors are the $\delta^{18} \mathrm{O}$ value $\left(\delta^{18} \mathrm{O}_{\mathrm{w}}\right)$ of the precipitating fluid (Urey 1947; Epstein and Mayeda 1953), mineralogy (Tarutani et al. 1969), and "vital effects" in carbonate secreting organisms (McConnaughey 2003). The slope of the $\delta^{18} \mathrm{O} /$ temperature relationship in carbonates is commonly assumed to be in the range from -0.2 to $-0.25 \% /{ }^{\circ} \mathrm{C}$ (Grossman and $\mathrm{Ku} 1986$; Bemis et al. 1998), resulting in a decrease of $0.8-1 \% o \delta^{18} \mathrm{O}$ for a four degree increase in temperature.

Carbonates from Kepulauan Seribu are characterized by much lower $\delta^{18} \mathrm{O}$ values compared to other carbonate systems (Fig. 8). This can be explained by the combined effect of high sea surface temperatures and low $\delta^{18} \mathrm{O}_{\mathrm{w}}$ in the Java Sea (Fig. 9). Modelling results confirm that for carbonates precipitated in equilibrium with seawater, SE Asia is globally the region with the most negative $\delta^{18} \mathrm{O}$ signature (Fig. 9c). Within the IPWP the differences in temperature are small (Fig. 9a), but $\delta^{18} \mathrm{O}$ water is significantly reduced in SE Asia compared to e.g. the central equatorial Indian Ocean or Pacific (Fig. 9b).

Differences in hydrology are reflected in the lower $\delta^{18} \mathrm{O}$ values of a Porites coral from Kepulauan Seribu compared to those from the Seychelles and Chagos (Fig. 8). The difference of more than $1 \%$ in $\delta^{18} \mathrm{O}$ is more than can be explained by intercolony offsets (Sayani et al. 2019) or the temperature difference of $\sim{ }^{\circ} \mathrm{C}$ between the Java Sea and 


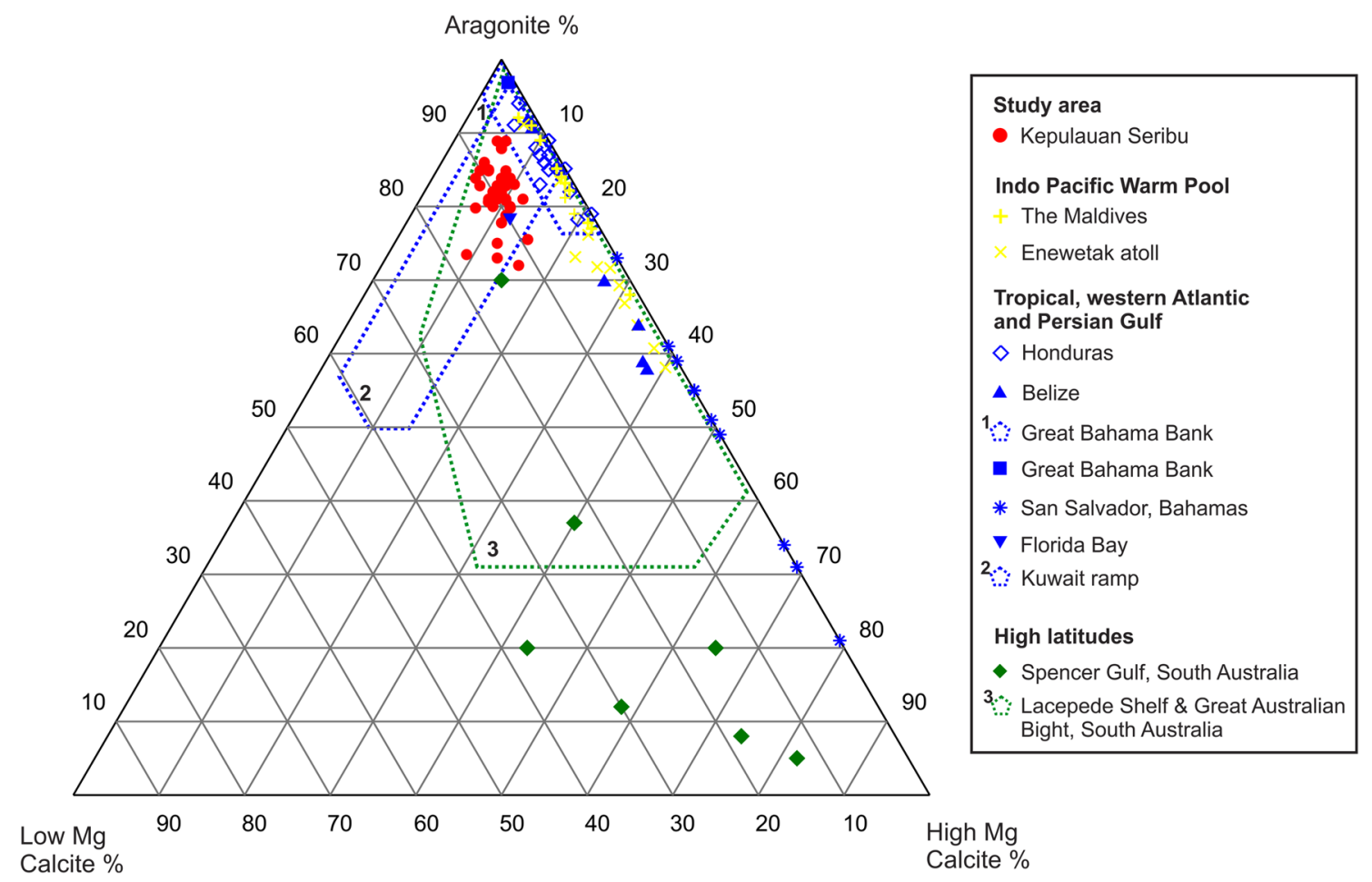

Fig. 10 Mineralogical composition of bulk surface sediment from Panggang reef platform, Kepulauan Seribu (normalize to only carbonate mineral phases). Carbonate mineralogy of Holocene bulk surface sediment from the Maldives (Gischler 2006), Enewetak Atoll (Weber and Schmalz 1968), Honduras, Caribbean oceanic barrier reef (Schmitt and Gischler 2017), Belize (Weber and Schmalz 1968; Gischler et al. 2012, 2013), Great Bahama Bank (Purdy 1963;

the other two sites. Most of the difference therefore can be attributed to the contrasting $\delta^{18} \mathrm{O}$ seawater values, which based on the difference in salinity should be around $0.9-1.1$ $\% / \delta^{18} \mathrm{O}$ assuming a slope of $0.22 \%$ for the salinity $/ \delta^{18} \mathrm{O}$ relationship (Fairbanks et al. 1997). The lower $\delta^{18} \mathrm{O}$ seawater values in the Java Sea result from heavy precipitation and increased runoff, and are also influenced by the $\delta^{18} \mathrm{O}_{\mathrm{w}}$ of the precipitation itself via the so called "amount effect" (Rozanski et al. 1993; Lau and Yang 2003).

Facies also could influence the $\delta^{18} \mathrm{O}$ signature of bulk sediments due to differences in the "vital effects" of carbonate producing organisms (McConnaughey 2003; McConnaughey and Gillikin 2008) and mineralogy (Tarutani et al. 1969). However, the different $\delta^{18} \mathrm{O}$ values for individual grain types to a large extent seem to average out for bulk samples (Gischler et al. 2012). This results in relatively large overlaps between facies in most atolls, barrier reefs and platforms (Gischler et al. 2012), showing that the influence of facies in these settings is limited.

The carbonate mineralogy of shallow water $(<20 \mathrm{~m})$ bulk sediments in the tropics and subtropics (IPWP, TWA) is predominantly composed of aragonite and HMC, with
Reijmer et al. 2009), San Salvador, Bahamas (Husinec et al. 2019), Florida Bay (Ginsburg 1956), Kuwait ramp (Gischler and Lomando 2005), Spencer Gulf, South Australia (O'Connell and James 2015), Lacepede Shelf and Great Australian Bight, South Australia (James et al. 2005) are shown for comparison. All sample are from shallow water $(<20 \mathrm{~m})$ except sample from South Australia

LMC usually present in low quantities $<10 \%$ (Fig. 10) (Ginsburg 1956; Purdy 1963; Weber and Schmalz 1968; Gischler 2006; Reijmer et al. 2009; Gischler et al. 2013; Schmitt and Gischler 2017; Husinec et al. 2019). The only exception is the Kuwait ramp system that shows LMC contents of up to $40 \%$ (Gischler and Lomando 2005). In reef atoll and platform systems higher LMC content $>10 \%$ are usually spatially restricted and related to local dominance of rotaliid foraminifers, such as Amphistegina (Weber and Woodhead 1972), contribution from calcite precipitated in meteoric waters (Swart and Kramer 1997) or from microbial activity (Pusey 1975; Purdy and Gischler 2003). Otherwise, higher LMC (7-14\%) contents generally occur only in deeper water between 20 and $70 \mathrm{~m}$, mainly contributed from planktonic foraminifers, coccoliths and molluscs (Weber and Schmalz 1968; Gischler 2006). Aragonite also dominates the mineralogy of the study area in Kepulauan Seribu but HMC and LMC occur in nearly equal proportions. The main mineralogical difference to other reefal systems in the IPWP is the occurrence of clastic mineral phases (Table 1) and a higher LMC content $(\sim 10 \%)$ in the shallow water sediment (Fig. 10). 
Opposed to open ocean settings, the semi-enclosed Java Sea is influenced by river runoff. Terrestrial sediments reaching Kepulauan Seribu (Table 1) most likely are derived from Sumatran rivers, since oceanic currents isolate Kepulauan Seribu from sediment input from Java and Kalimantan (Tomascik et al. 1997; Jordan 1998). The suspended particulate matter promotes oligophotic conditions in relatively shallow water. Wilson and Vecsei (2005) argued that oligophotic conditions in water depth below $20 \mathrm{~m}$ are typical for humid equatorial carbonate systems in SE Asia and would favor the deposition of e.g. relatively calcite-rich foramol facies. Foramol facies in Kepulauan Seribu dominates in water depth below $27 \mathrm{~m}$ (Jordan 1998). In water depth $<20 \mathrm{~m}$, rotaliid foraminifers contribute to LMC (Table 4) but their abundance is not high enough to explain the generally increased LMC content. Another important source of LMC in Kepulauan Seribu seems to be mixed aragonite-calcite bivalve shells. More mineralogical analysis from humid equatorial settings are needed to test if the increased LMC content observed in Kepulauan Seribu is a common feature of shallow water $(<20 \mathrm{~m})$ reef systems in humid, equatorial settings.

Fine fraction sediment from the Panggang reef platform is showing a higher HMC compared to the bulk fraction, likely related to micritization and bioerosion. Higher HMC contents in the fine fraction are also found in Belize, the potential source is micritization of skeletal grains to $\mathrm{Mg}$ calcite (Weber and Schmalz 1968). Micritization of skeletal grains is also an important diagenetic process in other shallow marine carbonate platforms, e.g. The Bahamas where the grains are altered to aragonite (Purdy 1963; Bathurst 1966; Kendall and Skipwith 1969; Trumbull 1988). Preferential alteration of the carbonate grains into high $\mathrm{Mg}$ calcite is potentially controlled by lower aragonite supersaturation in water off Kepulauan Seribu. Fresh water influx from rivers promotes low salinities in the semi-enclosed seas of SE Asia, leading to relatively low aragonite supersaturation compared to more arid regions as the tropical, western Atlantic (Park et al. 2010). Seawater $\mathrm{Mg}$ :Ca ratios are another important control on carbonate mineralogy, with lower Mg:Ca favouring calcite precipitation at a given temperature (Morse et al. 1997). A recent compilation of $\mathrm{Mg}$ :Ca ratios in seawater shows that values are not spatially constant but influenced by river waters with low Mg:Ca values (Lebrato et al. 2020). No seawater data is available for the semi-enclosed seas of SE Asia, but the high riverine input could potentially also reduce the $\mathrm{Mg}$ : $\mathrm{Ca}$ ratios in the Java Sea. Depending on the magnitude of this effect, the reduced $\mathrm{Mg}: \mathrm{Ca}$ ratios could facilitate the precipitation of calcite in the study area.

The mineralogical composition in the shallow water $(<20 \mathrm{~m})$, photozoan dominated carbonates from Kepulauan Seribu overlaps with the most aragonite rich part of the cool water carbonate field (Fig. 10). However, based on the dominance of reefal material, the sediments can be clearly differentiated from heterozoan dominated cool water carbonates. This might be more difficult for the foramol facies that dominates at the toe of slope and below (Jordan 1998). Wilson (2012) pointed out that oligophotic, humid equatorial carbonates share many similarities with cool water carbonates. However, a marked difference is that HMC components in Panggang have much higher Mg-contents (11.7-14 mol\% $\mathrm{MgCO}_{3}$ ), compared to 4-12 $\mathrm{mol} \% \mathrm{MgCO}_{3}$ in carbonate sediment of e.g. South Australia (James et al. 2005; O'Connell and James 2015). This difference can be best explained by the different water temperature between both regions. The $\mathrm{MgCO}_{3}$ content in HMC of calcareous marine organism is strongly influenced by the water temperature, with an increase in $\mathrm{Mg}$-content related to higher temperatures (Chave 1954). However, this difference in Mg-content will not be helpful in the distinction of ancient carbonates since $\mathrm{HMC}$ is losing Mg from the crystal lattice relatively early during diagenesis (Brachert and Dullo 2000).

\section{Conclusion}

The reef platforms of Kepulauan Seribu represent the shallow water, photozoan-dominated part of a humid equatorial carbonate system. The mineralogical and/or isotopic characteristic of their surface sediments are distinct from most other carbonate systems and likely are representative for many SE Asian reef systems affected by river runoff.

Biogenic debris from corals and molluscs are the most important grain types. Minor components include benthic foraminifers, echinoderms, red algae and the green alga $\mathrm{Hal}$ imeda, while non-skeletal grains are very rare. Aragonite is the dominant mineral phase, mainly contributed from corals and to a lesser degree by molluscs. LMC and HMC occur in fairly similar amounts in all facies. Bivalves (calcitic and bimineralic) and some rotaliid foraminifers (e.g. Amphistegina and Elphidium) contribute LMC. Most red algae (e.g. Amphiroa), echinoderms, and benthic foraminifers (e.g. Calcarina and Operculina) are important sources for HMC. An increased HMC content in the fine fraction could be related to preferential breakdown of HMC components, possibly from red algae growing on sea grass. Alternatively, micritization and bioerosion could contribute to increased HMC. Small amounts of siliciclastic minerals (quartz and smectite) are preferentially deposited in deeper waters below the wave base. This shows that despite its relatively isolated position, Kepulauan Seribu is affected by sediment-laden river runoff.

The main mineralogical difference between carbonates from Kepulauan Seribu and most other reefal systems in the tropic western Atlantic and Indo-Pacific Warm Pool area, is the widespread presence of $>10 \%$ LMC content in the shallow water sediment. The LMC is contributed 
by organisms that are not or less light dependent (bivalves and some rotaliid foraminifers) and therefore can thrive under oligophotic conditions. The suspended particulate matter from terrestrial runoff likely limits the depth of the euphotic zone. This is reflected in the deposition of foramol facies below a depth of $\sim 28 \mathrm{~m}$ (Jordan 1998), but seems to already affect the sediments in the upper $20 \mathrm{~m}$. Compared to similar foramol facies from higher latitudes, the $\mathrm{Mg}$ content in HMC components from Kepulauan Seribu is much higher due to the different water temperature between both regions.

The $\delta^{13} \mathrm{C}$ signature of carbonates from Kepulauan Seribu is considerably more negative compared to nearly all other platform and reef systems. This is likely due to the combination of low $\delta^{13} \mathrm{C}_{\text {DIC }}$ in surface waters and the lack of green algal grains and inorganically precipitated carbonates. The $\delta^{13} \mathrm{C}$ in surface waters likely is reduced by ${ }^{12} \mathrm{C}$-enriched input of DIC to river water from riverside mangroves. Corals as the predominant skeletal material and major aragonite producer also exert an influence on the bulk isotope composition, resulting in depletion of heavy isotopes values due to kinetic "vital effects". Low light intensity due to turbid water in the semi-enclosed basin of the Java Sea potentially hampers photosynthesis, which further reduces skeletal $\delta^{13} \mathrm{C}$ values in corals due to metabolic effects. The Suess effect, which is caused by the combustion of fossil fuel, leads to a decline of skeletal $\delta^{13} \mathrm{C}$ over the twentieth century in corals. This signal might not be recorded to its full extent in the bulk sediment yet, which represents a grain mixture of different ages.

Carbonates from Kepulauan Seribu are also characterized by much lower $\delta^{18} \mathrm{O}$ values compared to other carbonate systems, due to high sea surface temperatures and low $\delta^{18} \mathrm{O}_{\mathrm{w}}$ in the Java Sea. Deep atmospheric convection leads to heavy precipitation and increased fluvial runoff of very ${ }^{18} \mathrm{O}$-depleted water to the semi-enclosed Java Sea. The relatively low $\delta^{18} \mathrm{O}$ of benthic foraminifers and bivalves from Kepulauan Seribu shows that the oxygen isotope signature can be used to distinguish foramol facies from oligophotic equatorial carbonates and cool water carbonates in the rock record.

Acknowledgements The authors are grateful to Lembaga Pengelola Dana Pendidikan (LPDP) (Grant No. PRJ-4137/LPDP.3/2016) who awarded a scholarship and dissertation fund to Dwi Amanda Utami Nasution. We are grateful to Prof. Miriam Pfeiffer for providing stable isotope data of Porites corals from the Seychelles and Chagos and for commenting an earlier version of the manuscript. Dr. Nils Andersen (Kiel) is acknowledged for stable isotope analysis. Uwe Wollenberg is thanked for his help with XRD measurement. We thank two anonymous reviewers for insightful comments on the manuscript. This work was partially supported by National Geographic Explorer Grant No CP 087R 17. We acknowledge Google Earth for online imagery and QGIS (ver. 3.14.1-Pi) for GIS software.
Author contributions Dwi Amanda Utami: funding acquisition, resources, investigation, formal analysis, visualization, writing - original draft, writing — review and editing. Lars Reuning: supervision, resources, conceptualization, formal analysis, validation, writingoriginal draft, writing — review and editing. Maximillian Hallenberger: investigation, writing — review and editing. Sri Yudawati Cahyarini: resources, writing-review and editing.

Funding Open Access funding enabled and organized by Projekt DEAL.

Open Access This article is licensed under a Creative Commons Attribution 4.0 International License, which permits use, sharing, adaptation, distribution and reproduction in any medium or format, as long as you give appropriate credit to the original author(s) and the source, provide a link to the Creative Commons licence, and indicate if changes were made. The images or other third party material in this article are included in the article's Creative Commons licence, unless indicated otherwise in a credit line to the material. If material is not included in the article's Creative Commons licence and your intended use is not permitted by statutory regulation or exceeds the permitted use, you will need to obtain permission directly from the copyright holder. To view a copy of this licence, visit http://creativecommons.org/licenses/by/4.0/.

\section{References}

Aharon P (1991) Recorders of reef environment histories: stable isotopes in corals, giant clams, and calcareous algae. Coral Reefs 10:71-90. https://doi.org/10.1007/BF00571826

Allison N, Tudhope AW, Fallick AE (1996) Factors influencing the stable carbon and oxygen isotopic composition of Porites lutea coral skeletons from Phuket, South Thailand. Coral Reefs 15:43-57. https://doi.org/10.1007/BF01626076

Andrews JE (1991) Geochemical indicators of depositional and early diagenetic facies in Holocene carbonate muds, and their preservation potential during stabilisation. Chem Geol 93:267-289. https://doi.org/10.1016/0009-2541(91)90118-B

Atmadja WS (1977) Notes on the Distribution of Red Algae (Rhodophyta) on the Coral Reef of Pari Islands, Seribu Islands. Mar Res Indones 17:15-20. https://doi.org/10.14203/mri.v17i0.348

Bathurst RGC (1966) Boring algae, micrite envelopes and lithification of molluscan biosparites. Geol J 5:15-32. https://doi. org/10.1002/gj.3350050104

Baum G, Januar HI, Ferse SCA, Kunzmann A (2015) Local and regional impacts of pollution on coral reefs along the Thousand Islands North of the Megacity Jakarta. Indonesia PLoS One 10:e0138271. https://doi.org/10.1371/journal.pone.0138271

Bemis BE, Spero HJ, Bijma J, Lea DW (1998) Reevaluation of the oxygen isotopic composition of planktonic foraminifera: experimental results and revised paleotemperature equations. Paleoceanography 13:150-160. https://doi.org/10.1029/98PA00070

Blackmon PD, Todd R (1959) Mineralogy of some foraminifera as related to their classification and ecology. J Paleontol 33:1-15. https://doi.org/10.2307/1300802

Blott SJ, Pye K (2001) Gradistat: a grain size distribution and statistics package for the analysis of unconsolidated sediments. Earth Surf Process Landforms 26:1237-1248. https://doi.org/10.1002/ esp. 261

Brachert TC, Dullo WC (2000) Shallow burial diagenesis of skeletal carbonates: Selective loss of aragonite shell material (Miocene to Recent, Queensland Plateau and Queensland Trough, NE Australia)_implications for shallow cool-water carbonates. 
Sediment Geol 136:169-187. https://doi.org/10.1016/S0037 -0738(00)00096-8

Cahyarini SY, Zinke J, Troelstra S et al (2016) Coral Sr/Ca-based sea surface temperature and air temperature variability from the inshore and offshore corals in the Seribu Islands, Indonesia. Mar Pollut Bull 110:694-700. https://doi.org/10.1016/J.MARPO LBUL.2016.04.052

Chave KE (1954) Aspects of the biogeochemistry of magnesium. 1. Calcareous marine organisms. J Geol 62:266-283. https://doi. org/10.1086/626162

Damar A, Colijn F, Hesse K-J, Wardiatno Y (2012) The eutrophication states of Jakarta, Lampung and Semangka Bays: nutrient and phytoplankton dynamics in Indonesia tropical waters. J Trop Biol Conserv 9:61-81

Epstein S, Mayeda T (1953) Variation of O18 content of waters from natural sources. Geochim Cosmochim Acta 4:213-224. https:// doi.org/10.1016/0016-7037(53)90051-9

Fairbanks RG, Evans MN, Rubenstone JL et al (1997) Evaluating climate indices and their geochemical proxies measured in corals. Coral Reefs 16:93-100. https://doi.org/10.1007/s003380050245

Farhan AR, Lim S (2012) Vulnerability assessment of ecological conditions in Seribu Islands, Indonesia. Ocean Coast Manag 65:114. https://doi.org/10.1016/j.ocecoaman.2012.04.015

Gallagher SJ, Reuning L, Himmler T et al (2018) The enigma of rare Quaternary oolites in the Indian and Pacific Oceans: a result of global oceanographic physicochemical conditions or a sampling bias? Quat Sci Rev 200:114-122. https://doi.org/10.1016/j.quasc irev.2018.09.028

Gillespie JL, Nelson CS (1997) Mixed Siliciclastic Skeletal Carbonate Facies on Wanganui Shelf, New Zealand: A Contribution to the Temperate Carbonate Model. In: James N., Clarke J. (eds) Coolwater Carbonates. Special Publications of SEPM, pp 127-140

Ginsburg RN (1956) Environmental relationships of grain size and constituent particles in some south Florida carbonate sediments. Am Assoc Pet Geol Bull 40:2384-2427. https://doi. org/10.1306/5CEAE598-16BB-11D7-8645000102C1865D

Gischler E (2006) Sedimentation on rasdhoo and ari atolls, maldives, Indian ocean. Facies 52:341-360. https://doi.org/10.1007/s1034 7-005-0031-3

Gischler E (2011) Sedimentary Facies of Bora Bora, Darwin's Type Barrier Reef (Society Islands, South Pacific): the unexpected occurrence of non-skeletal grains. J Sediment Res 81:1-17. https ://doi.org/10.2110/jsr.2011.4

Gischler E, Lomando AJ (1999) Recent sedimentary facies of isolated carbonate platforms, Belize-Yucatan system, Central America. J Sediment Res 69:747-763. https://doi.org/10.2110/jsr.69.747

Gischler E, Lomando AJ (2005) Offshore sedimentary facies of a modern carbonate ramp, Kuwait, northwestern Arabian-Persian Gulf. Facies 50:443-462. https://doi.org/10.1007/s10347-004-0027-4

Gischler E, Zingeler D (2002) The origin of carbonate mud in isolated carbonate platforms of Belize, Central America. Int J Earth Sci 91:1054-1070. https://doi.org/10.1007/s00531-002-0288-5

Gischler E, Swart PK, Lomando AJ (2012) Stable Isotopes of Carbon and Oxygen in Modern Sediments of Carbonate Platforms, Barrier Reefs, Atolls and Ramps: Patterns and Implications. in: Perspectives in Carbonate Geology: A Tribute to the Career of Robert Nathan Ginsburg. Int Assoc Sedimentol Spec Publ 41:61-74

Gischler E, Dietrich S, Harris D et al (2013) A comparative study of modern carbonate mud in reefs and carbonate platforms: mostly biogenic, some precipitated. Sediment Geol 292:36-55. https:// doi.org/10.1016/j.sedgeo.2013.04.003

González LA, Lohmann KC (1985) Carbon and oxygen isotopic composition of Holocene reefal carbonates. Geology 13:811-814

Grossman EL, Ku T-L (1986) Oxygen and carbon isotope fractionation in biogenic aragonite: temperature effects. Chem Geol
Isot Geosci Sect 59:59-74. https://doi.org/10.1016/01689622(86)90057-6

Grottoli AG (2002) Effect of light and brine shrimp on skeletal $\delta 13 \mathrm{C}$ in the Hawaiian coral Porites compressa: a tank experiment. Geochim Cosmochim Acta 66:1955-1967. https://doi.org/10.1016/ S0016-7037(01)00901-2

Grottoli AG, Wellington GM (1999) Effect of light and zooplankton on skeletal $\delta 13 \mathrm{C}$ values in the eastern Pacific corals Pavona clavus and Pavona gigantea. Coral Reefs 18:29-41. https://doi. org/10.1007/s003380050150

Hallenberger M, Reuning L, Gallagher SJ et al (2019) Increased fluvial runoff terminated inorganic aragonite precipitation on the Northwest Shelf of Australia during the early Holocene. Sci Rep 9:1-9. https://doi.org/10.1038/s41598-019-54981-7

Hammer Ø, Harper DAT, Ryan PD (2001) Past: paleontological statistics software package for education and data analysis. Palaeontol Electron 4:178

Hamzah F, Agustiadi T, Susanto RD et al (2020) Dynamics of the carbonate system in the Western Indonesian Seas during the Southeast Monsoon. J Geophys Res Ocean 125:1-18. https:// doi.org/10.1029/2018JC014912

Heikoop JM, Risk MJ, Lazier AV et al (2000) Nitrogen-15 signals of anthropogenic nutrient loading in reef corals. Mar Pollut Bull 40:628-636. https://doi.org/10.1016/S0025-326X(00)00006-0

Husinec A, Loree PE, Murphy JT (2019) Degrading windward patch reefs and processes influencing composition, mineralogy, and stable-isotope record of peri-reefal sediment, San Salvador Island. Bahamas Facies 65:39. https://doi.org/10.1007/s1034 7-019-0583-2

Ishiwa T, Yokoyama Y, Reuning L et al (2019) Australian Summer Monsoon variability in the past 14,000 years revealed by IODP Expedition 356 sediments. Prog Earth Planet Sci 6:1-10. https ://doi.org/10.1186/s40645-019-0262-5

James NP, Bone Y, Kyser TK (2005) Where has all the aragonite gone? mineralogy of holocene neritic cool-water carbonates, Southern Australia. J Sediment Res 75:454-463. https://doi.org/10.2110/ jsr.2005.035

Jordan CF (1998) The Sedimentology of Kepulauan Seribu: A Modern Patch Reef Complex in the West Java Sea, Indonesia. Indones Pet Assoc 1-81

Keeling CD (1979) The Suess effect: 13Carbon-14Carbon interrelations. Environ Int 2:229-300. https://doi.org/10.1016/01604120(79)90005-9

Kendall CGSC, Skipwith PA (1969) Holocene shallow-water carbonate and evaporite sediments of Khor al Bazam, Abu Dhabi, Southwest Persian Gulf. Am Assoc Pet Geol Bull 53:841-869. https ://doi.org/10.1306/5D25C803-16C1-11D7-8645000102C1865D

Koropitan AF, Ikeda M (2016) Influences of physical processes and anthropogenic influx on biogeochemical cycle in the java sea: numerical model experiment. Procedia Environ Sci 33:532-552. https://doi.org/10.1016/j.proenv.2016.03.106

Land LS (1970) Carbonate mud; production by epibiont growth on Thalassia testudinum. J Sediment Res 40:1361-1363. https://doi. org/10.1306/74d721b7-2b21-11d7-8648000102c1865d

Lau K-M, Yang S (2003) Walker Circulation. In: Holton JR (ed) Encyclopedia of Atmospheric Sciences. Academic Press, Canbridge, pp 2505-2510

Lebrato M, Garbe-Schönberg D, Müller MN et al (2020) Global variability in seawater $\mathrm{Mg}$ : $\mathrm{Ca}$ and $\mathrm{Sr}$ : Ca ratios in the modern ocean. Proc Natl Acad Sci 117:22281-22292. https://doi.org/10.1073/ pnas. 1918943117

Linsley BK, Dunbar RB, Dassié EP et al (2019) Coral carbon isotope sensitivity to growth rate and water depth with paleo-sea level implications. Nat Commun 10:2056. https://doi.org/10.1038/ s41467-019-10054-x 
Lumsden DN (1979) Discrepancy between thin-section and X-ray estimates of dolomite in limestone. SEPM J Sediment Res 49:429435. https://doi.org/10.1306/212F7761-2B24-11D7-8648000102 C1865D

Madden RHC, Wilson MEJ (2012) Diagenesis of neogene delta-front patch reefs: alteration of coastal, siliciclastic-influenced carbonates from humid equatorial regions. J Sediment Res 82:871-888. https://doi.org/10.2110/jsr.2012.26

Madduppa HH (2013) Dynamics of fish diversity across an environmental gradient in the Seribu Islands reefs off Jakarta. Biodiversitas. J Biol Divers 14:17-24. https://doi.org/10.13057/biodi v/d140103

Maeda A, Fujita K, Horikawa K et al (2017) Evaluation of oxygen isotope and $\mathrm{Mg} / \mathrm{Ca}$ ratios in high-magnesium calcite from benthic foraminifera as a proxy for water temperature. J Geophys Res Biogeosci 122:185-199. https://doi.org/10.1002/2016JG003587

McConnaughey T (1989) $13 \mathrm{C}$ and $18 \mathrm{O}$ isotopic disequilibrium in biological carbonates: I. Patterns Geochim Cosmochim Acta 53:151-162. https://doi.org/10.1016/0016-7037(89)90282-2

McConnaughey TA (2003) Sub-equilibrium oxygen-18 and carbon-13 levels in biological carbonates: carbonate and kinetic models. Coral Reefs 22:316-327. https://doi.org/10.1007/s0033 8-003-0325-2

McConnaughey TA, Gillikin DP (2008) Carbon isotopes in mollusk shell carbonates. Geo-Marine Lett 28:287-299. https://doi. org/10.1007/s00367-008-0116-4

Milliman JD, Müller G, Förstner U (1974) Recent Sedimentary Carbonates. Springer, Berlin Heidelberg

Milliman JD, Farnsworth KL, Albertin CS (1999) Flux and fate of fluvial sediments leaving large islands in the East Indies. J Sea Res 41:97-107. https://doi.org/10.1016/S1385-1101(98)00040-9

Miyajima T, Tsuboi Y, Tanaka Y, Koike I (2009) Export of inorganic carbon from two Southeast Asian mangrove forests to adjacent estuaries as estimated by the stable isotope composition of dissolved inorganic carbon. J Geophys Res 114:G01024. https://doi. org/10.1029/2008JG000861

Morse JW, Wang Q, Tsio MY (1997) Influences of temperature and $\mathrm{Mg}$ : Ca ratio on $\mathrm{CaCO} 3$ precipitates from seawater. Geology 25:85-87. https://doi.org/10.1130/0091-7613(1997)025\%3c008 5:IOTAMC\%3e2.3.CO;2

Moyer RP, Grottoli AG (2011) Coral skeletal carbon isotopes $(\delta 13 \mathrm{C}$ and $\Delta 14 \mathrm{C}$ ) record the delivery of terrestrial carbon to the coastal waters of Puerto Rico. Coral Reefs 30:791-802. https://doi. org/10.1007/s00338-011-0758-y

O'Connell LG, James NP (2015) Composition and genesis of temperate, shallow-marine carbonate muds: spencer gulf, South Australia. J Sediment Res 85:1275-1291. https://doi.org/10.2110/ jsr.2015.73

Park RK, Siemers CT, Brown AA (1992) Holocene carbonate sedimentation, Pulau Seribu, Java Sea-the third dimension. In: Carbonate Rocks and Reservoirs of Indonesia, A Core Workshop. Indonesian Petroleum Association, Jakarta. pp 2-1 - 2-15

Park RK, Crevello PD, Hantoro W (2010) Equatorial Carbonate Depositional Systems of Indonesia. In: Morgan WA, George AD, Harris PM, et al. (eds) Cenozoic carbonate systems of Australasia. SEPM Special Publication 95, Tulsa, Oklahoma, pp 41-77

Perry CT, Salter MA, Morgan KM, Harborne AR (2019) Census estimates of algal and epiphytic carbonate production highlight tropical seagrass meadows as sediment production hotspots. Front Mar Sci 6:120. https://doi.org/10.3389/fmars.2019.00120

Pfeiffer M, Dullo WC (2006) Monsoon-induced cooling of the western equatorial Indian Ocean as recorded in coral oxygen isotope records from the Seychelles covering the period of 1840 1994AD. Quat Sci Rev 25:993-1009. https://doi.org/10.1016/j. quascirev.2005.11.005
Pfeiffer M, Dullo WC, Eisenhauer A (2004) Variability of the intertropical convergence zone recorded in coral isotopic records from the central indian Ocean (Chagos Archipelago). Quat Res 61:245-255. https://doi.org/10.1016/j.yqres.2004.02.009

Poerbandono (2016) Wind characteristics and the associated risk of erosion in Seribu Islands patch reef complexes, Java Sea, Indonesia. In: The 5th international symposium on earthhazard and disaster mitigation. AIP Conf. Proc. p 080001

Purdy EG (1963) Recent calcium carbonate facies of the great Bahama Bank. 1. Petrography and Reaction Groups. J Geol 71:334-355

Purdy EG, Gischler E (2003) The Belize margin revisited: 1. Holocene marine facies. Int J Earth Sci 92:532-551. https://doi. org/10.1007/s00531-003-0324-0

Pusey WC (1975) Holocene Carbonate Sedimentation on Northern Belize Shelf: Part 1. In: Belize Shelf - Carbonate Sediments, Clastic Sediments, and Ecology. AAPG Special Volumes, pp 131-165

Reid RP, Macintyre IG (2000) Microboring versus recrystallization: further insight into the micritization process. SEPM J Sediment Res 70(2):24-28. https://doi.org/10.1306/d4268b76-2b2611d7-8648000102c1865d

Reijmer JJG, Swart PK, Bauch T et al (2009) A re-evaluation of facies on Great Bahama Bank I: new facies maps of western Great Bahama Bank. Int Assoc Spec Publ 41:29-46. https:// doi.org/10.1002/9781444312065.ch3

Renema W (2008) Habitat selective factors influencing the distribution of larger benthic foraminiferal assemblages over the Kepulauan Seribu. Mar Micropaleontol 68:286-298. https:// doi.org/10.1016/j.marmicro.2008.06.002

Romanek CS, Grossman EL, Morse JW (1992) Carbon isotopic fractionation in synthetic aragonite and calcite: effects of temperature and precipitation rate. Geochim Cosmochim Acta 56:419-430. https://doi.org/10.1016/0016-7037(92)90142-6

Rozanski K, Araguás-Araguás L, Gonfiantini R (1993) Isotopic Patterns in Modern Global Precipitation. In: Swart PK, Lohmann KC, Mckenzie J, Savin S (eds) Geophysical Monograph Series. AGU Books Board, pp 1-36

Rubinson M, Clayton RN (1969) Carbon-13 fractionation between aragonite and calcite. Geochim Cosmochim Acta 33:997-1002. https://doi.org/10.1016/0016-7037(69)90109-4

Salter MA, Perry CT, Wilson RW (2012) Production of mud-grade carbonates by marine fish: crystalline products and their sedimentary significance. Sedimentology 59:2172-2198. https:// doi.org/10.1111/j.1365-3091.2012.01339.x

Salter MA, Harborne AR, Perry CT, Wilson RW (2017) Phase heterogeneity in carbonate production by marine fish influences their roles in sediment generation and the inorganic carbon cycle. Sci Rep 7:1-15. https://doi.org/10.1038/s41598-01700787-4

Salter MA, Perry CT, Stuart-Smith RD et al (2018) Reef fish carbonate production assessments highlight regional variation in sedimentary significance. Geology 46:699-702. https://doi.org/10.1130/ G45286.1

Saraswati PK, Seto K, Nomura R (2004) Oxygen and carbon isotopic variation in co-existing larger foraminifera from a reef flat at Akajima, Okinawa, Japan. Mar Micropaleontol 50:339-349. https://doi.org/10.1016/S0377-8398(03)00099-9

Sayani HR, Cobb KM, DeLong K et al (2019) Intercolony $\delta 180$ and $\mathrm{Sr} / \mathrm{Ca}$ variability among Porites spp. corals at Palmyra Atoll: toward more robust coral-based estimates of climate. Geochemistry, Geophys Geosystems 20:5270-5284. https://doi. org/10.1029/2019GC008420

Schlager W (1992) Sedimentology and sequence stratigraphy of reefs and carbonate platforms. The American Association of Petroleum Geologists; Continuing Education Course Note Series, 34, Tulsa, Oklahoma 
Schmitt D, Gischler E (2017) Recent sedimentary facies of Roatan (Bay Islands, Honduras), a Caribbean oceanic barrier reef system. Facies 63:5. https://doi.org/10.1007/s10347-016-0485-5

Schmidt GA, Bigg GR, Rohling EJ (1999) Global seawater oxygen-18 database - v1.22. Available at https://data.giss.nasa.gov/o18data/

Schroeder JH (1972) Fabrics and sequences of submarine carbonate cements in Holocene Bermuda cup reefs. Geol Rundschau 61:708-730. https://doi.org/10.1007/BF01896342

Scrutton M (1976a) Aspects carbonate sedimentation in Indonesia. In: Indonesian petroleum association, proceeding 5 th annual convention. pp 179-193

Scrutton M (1976b) Modern reefs in the west java sea. In: Indonesian petroleum association. Proceeding 5th annual convention, pp 14-36

Smith SV, Kroopnick P (1981) Carbon-13 isotopic fractionation as a measure of aquatic metabolism. Nature 294:252-253. https://doi. org/10.1038/294252a0

Sofian I, Kozai K (2007) Literature review of the climatology of the Java Sea. Kobe Univ Repos Kernel 133-138

Swart PK (1983) Carbon and oxygen isotope fractionation in scleractinian corals: a review. Earth-Sci Rev 19:51-80. https://doi. org/10.1016/0012-8252(83)90076-4

Swart PK, Kramer PA (1997) Geology of Mud Islands in Florida Bay. In: Vacher H., Quinn T (eds) Geology and Hydrogeology of Carbonate Islands. In: Developments in Sedimentology 54. Elsevier B.V., pp 249-274

Swart PK, Price R (2002) Origin of salinity variations in Florida Bay. Limnol Oceanogr 47:1234-1241. https://doi.org/10.4319/ 10.2002.47.4.1234

Swart PK, Sternberg LDSL, Steinen R, Harrison SA (1989) Controls on the oxygen and hydrogen isotopic composition of the waters of Florida Bay, U.S.A. Chem Geol Isot Geosci Sect 79:113-123. https://doi.org/10.1016/0168-9622(89)90014-6

Swart PK, Reijmer JJG, Otto R (2009) A Re-Evaluation of Facies on Great Bahama Bank II: Variations in the $\delta 13 \mathrm{C}, \delta 18 \mathrm{O}$ and Mineralogy of Surface Sediments. Perspectives in Carbonate Geology. John Wiley \& Sons Ltd, Chichester, West Sussex, pp 47-59

Swart PK, Greer L, Rosenheim BE et al (2010) The 13C Suess effect in scleractinian corals mirror changes in the anthropogenic $\mathrm{CO} 2$ inventory of the surface oceans. Geophys Res Lett. https://doi. org/10.1029/2009GL041397

Tarutani T, Clayton RN, Mayeda TK (1969) The effect of polymorphism and magnesium substitution on oxygen isotope fractionation between calcium carbonate and water. Geochim Cosmochim Acta 33:987-996. https://doi.org/10.1016/0016-7037(69)90108 $-2$

Tomascik T, Mah AJ, Nontji A, Moosa MK (1997) The Ecology of the Indonesia Seas Volume VIII Part II. Oxford University
Trumbull WJ (1988) Depositional History of a Windward Open Marginal Lagoon: Northern Great Bahama Bank. University of North Carolina

Ueda K (2020) iNaturalist research-grade observations. iNaturalist.org. Occurrence dataset https://doi.org/10.15468/ab3s5x. Accessed 5 Dec 2020

Urey H (1947) The thermodynamic properties of isotopic substances. J Chem Soc 99:562-581. https://doi.org/10.1039/jr9470000562

Utami DA, Reuning L, Cahyarini SY (2018) Satellite- and field-based facies mapping of isolated carbonate platforms from the Kepulauan Seribu Complex, Indonesia. Depos Rec 4:255-273. https ://doi.org/10.1002/dep2.47

van der Meij SET, Moolenbeek RG, Hoeksema BW (2009) Decline of the Jakarta Bay molluscan fauna linked to human impact. Mar Pollut Bull 59:101-107. https://doi.org/10.1016/j.marpo lbul.2009.02.021

Völpel R, Paul A, Krandick A et al (2017) Stable water isotopes in the MITgcm. Geosci Model Dev 10:3125-3144. https://doi. org/10.5194/gmd-10-3125-2017

Weber JN, Schmalz RF (1968) Factors affecting the carbon and oxygen isotopic composition of marine carbonate sediments, Part III, Eniwetok Atoll. SEPM J Sediment Res 38:1270-1279. https:// doi.org/10.1306/74D71B4F-2B21-11D7-8648000102C1865D

Weber JN, Woodhead PMJ (1972) Carbonate Lagoon and Beach Sediments of Tarawa Atoll, Gilbert Islands. Atoll Res Bull 157:1-21. https://doi.org/10.5479/si.00775630.157.1

Wefer G, Berger WH (1991) Isotope paleontology: growth and composition of extant calcareous species. Mar Geol 100:207-248. https ://doi.org/10.1016/0025-3227(91)90234-U

Wefer G, Killingley JS, Lutze GF (1981) Stable isotopes in recent larger foraminifera. Palaeogeogr Palaeoclimatol Palaeoecol 33:253-270. https://doi.org/10.1016/0031-0182(81)90042-0

Wilson MEJ (2002) Cenozoic carbonates in Southeast Asia: implications for equatorial carbonate development. Sediment Geol 147:295-428. https://doi.org/10.1016/S0037-0738(01)00228-7

Wilson MEJ (2008) Global and regional influences on equatorial shallow-marine carbonates during the Cenozoic. Palaeogeogr Palaeoclimatol Palaeoecol 265:262-274. https://doi.org/10.1016/j. palaeo.2008.05.012

Wilson MEJ (2012) Equatorial carbonates: an earth systems approach. Sedimentology 59:1-31. https://doi.org/10.111 1/j.1365-3091.2011.01293.x

Wilson MEJ, Vecsei A (2005) The apparent paradox of abundant foramol facies in low latitudes: their environmental significance and effect on platform development. Earth-Science Rev 69:133-168. https://doi.org/10.1016/j.earscirev.2004.08.003 